\title{
Chapter 12 \\ Measuring Vulnerability to Flash Flood of Urban Dwellers
}

\author{
Md. Enamul Huq, Zhenfeng Shao, Ahmed Abdullah Al Dughairi, \\ Md. Nazirul Islam Sarker, Cai Bowen, Abdullah Al Mamun, \\ Nayyer Saleem, Akib Javed, and Md. Mahabubur Rahman
}

\begin{abstract}
Flash floods are unexpected, localized flood events that occur when an exceptional amount of rain falls happens over a short period of time. In South Asia, it is mostly disastrous, for example, in 2017 flash floods killed approximately 1200 people from India, Nepal, and Bangladesh. However, it is also common in Dhaka megacity, Bangladesh due to its geographic location, monsoon climatic condition
\end{abstract}

Md. E. Huq ( $\square)$

College of Environmental Science, Hohai University, Nanjing, China

e-mail: enamul.huq@hhu.edu.cn

Z. Shao $\cdot$ N. Saleem $\cdot$ A. Javed

State Key Laboratory of Information Engineering in Surveying, Mapping and Remote

Sensing, Wuhan University, 129 LuoyuRoad, Wuhan 430079, Hubei, China

e-mail: shaozhenfeng@whu.edu.cn

N. Saleem

e-mail: saleemnayyer@whu.edu.cn

A. Javed

e-mail: akibjaved@whu.edu.cn
A. A. Al Dughairi
Department of Geography, Faculty of Arabic Language and Social Studies, Qassim University, Qassim Burydah, Kingdom of Saudi Arabia

Md. N. I. Sarker

School of Political Science and Public Administration, Neijiang Normal University, Sichuan, China

C. Bowen

School of Remote Sensing and Information Engineering, Wuhan University, Wuhan, China e-mail: caibowen@whu.edu.cn
A. Al Mamun
Department of Mechanical Manufacturing Engineering, School of Mechanical and Automotive Engineering, South China University of Technology, Tianhe District, 381
Wushan Road, Guangzhou 510641, Guangdong, China
Md. M. Rahman
Department of Computer Science and Engineering, Bangladesh University of Business and Technology, Dhaka, Bangladesh 
and surrounding rivers. Though it is impossible to avoid them, the losses and damages of hazards can be reduced effectively by using appropriate techniques. This study aims to determine the responsible factors and measure the household vulnerability to flash flood as a tool of mitigation. The study has been conducted based on primary data. Therefore, data were collected from both slum and non-slum population to cover the entire urban habitats. Data were collected with a structured questionnaire based on five factors (social, economic, institutional, structural, and environmental) of vulnerability to flash flood. The key feature of this paper is to provide an insight into real picture of vulnerability to flash flood for urban habitants. Moreover, this practical approach is useful to quantify hazard-induced vulnerabilities not only for Dhaka megacity but also for other cities of the globe.

Keywords Flash flood • Factors of vulnerability • Urban • Slum • Non-slum • Dhaka megacity

\subsection{Introduction}

Bangladesh is known as a disaster-oriented country. Various kinds of natural hazards, such as floods, droughts, riverbank erosion, cyclones, and storm surges, occur in Bangladesh almost every year. Geographically, Bangladesh is a low, riparian country characterized by floodplains. For this reason, Bangladesh is exposed to floods as well as flash floods. As a result, the rural and urban areas of Bangladesh are vulnerable to flash flood disasters. Dhaka is the capital of Bangladesh. It is the largest and only megacity in the country. Due to rapid urbanization, the city has evolved into a megacity containing over 10 million people and accounting for $33 \%$ of the national urban population (Fakhruddin et al. 2019). Flooding is perhaps the best-known hazard for this megacity (Barua et al. 2016; Braun and Aßheuer 2011). Among other factors, the excessive population and a high number of residents living in slum areas (approximately $43 \%$ of the total city population) (Ahmed 2016) have made city dwellers more vulnerable to flash floods. Low socioeconomic status and dilapidated housing conditions are considered the main determinants of vulnerability to flash floods or other hazards. Vulnerability is differentiated socially and geographically. It is recognized that identifying and understanding the factors of vulnerability are imperative for assessing vulnerability (Chen et al. 2019; Huq et al. 2020b; Shao et al. 2020; Zakour and Swager 2018). The vulnerability of a population to large-scale hazards can be reduced by applying disaster management efforts. The measurement of local-level vulnerability is an important tool for identifying households' and local communities' capacities for managing disastrous situations (Adger 2006; Berrouet et al. 2018; Nayyer et al. 2019). Moreover, poor people who have no adequate protective power and insufficient abilities to cope with damage to their belongings and income are the most vulnerable to flash flood disasters (Aroca-Jiménez et al. 2018). 
Very few previous documents have measured vulnerability linked to flash floods, and generally pursued fragmented methods in which all the components of vulnerability were not thoroughly measured. Normally, vulnerability analysis exclusively covers the physical (Shah et al. 2018), social extent (Ogie and Pradhan 2019), physical infrastructure, and socioecological dimensions together (Hayes et al. 2019; Pandey et al. 2015). Some studies (Ahsan and Warner 2014; Aroca-Jiménez et al. 2018; Okayo et al. 2015) have included economic factor but within a limited number of indicators compared to the social factor. Subsequently, it is cumbersome to properly present the exact socio-financial framework and spatial differences of vulnerability. Indicators used in vulnerability assessments should comprise various factors that influence people's lives or society's social and financial dimensions. However, the indicator selection of existing studies still lacks these aspects, which leads to errors in vulnerability assessment. Since vulnerability assessment and adaptation are context-specific, they must focus on local socioeconomic and socioecological conditions to explore society's real pictures (Aroca-Jiménez et al. 2020; Kamruzzaman et al. 2020). Ruin et al. (2008) investigated flood exposure in France by connecting key parameters of floods and the vulnerability of victimized society. The authors incorporated several indicators into their vulnerability assessment of flood risk by highlighting dimensions of social life and geophysics. Shrestha et al. (2008) assessed flood vulnerability and pointed out two main dimensions: physical vulnerability and social vulnerability. Recently, Aroca-Jiménez et al. (2020) assessed urban flash floods by developing the integrated socioeconomic vulnerability index (ISEV), which comprises the main key components of vulnerability, including exposure, sensitivity, and resilience. The ISEV index also focuses on the socioeconomic dimension of the urban environment. In another study, de Andrade and Szlafsztein (2018) notably assessed vulnerability to seasonal and flash floods using perceptible and imperceptible elements of the index. Similarly, Pham et al. (2020) assessed vulnerability to flash floods and landslides at the household level in Vietnam. They mainly evaluated the extent of the vulnerability of marginal farmers living in remote areas to the harmful effects of natural hazards. Aroca-Jiménez et al. (2018) proposed a quantitative approach for exploring specific economic factors of flood vulnerability in Castilla y León, Spain.

It is evident from various studies that flash floods cause damage to physical infrastructures such as roads, communication infrastructure, local water supply systems, and housing. Therefore, the inhabitants of urban areas are not free from flash flood risks. However, only a few studies have focused on household vulnerability in urban areas that frequently face flash flooding or on the components and key factors of vulnerability in urban settings. Moreover, household vulnerability indices are not usually focused on or available for flash flood events in urban areas. Therefore, this study aims to identify the factors responsible for creating household vulnerability to flash floods and to reduce the existing or potential vulnerabilities of the slum and non-slum areas in Dhaka megacity. 


\subsection{Flash Floods in Bangladesh}

Flash flood is a common natural hazard worldwide that causes huge damage to assets and life. Flash floods are considered to be among the most serious natural hazards that cause high mortality (>5000 people/year) (Wmo and Gwp 2016). The recent 2019 floods in Bangladesh affected 2.1 million people and killed 104 people across 24 districts (Uddin et al. 2019). Every year, flash floods cover approximately $20.5 \%$ of Bangladesh and cause notable damage to livelihoods, assets, property, and lives (Ahmed et al. 2017). In 2014, people gained similar flash flood experiences when floods caused substantial damage to thousands of acres of cropland and forced the migration of 0.5 million people. A flood in 2015 killed 22 people and affected 1.8 million people (Gain et al. 2017). Similarly, floods in 2014 also caused huge damage to the assets and property of 4.6 million people, along with causing a large amount of riverbank erosion (Alam et al. 2020). Generally, heavy rainfall causes flash floods in Bangladesh; flash floods result from heavy rainfall in the hilly areas of Bangladesh and in neighboring countries. Forecasting flash flood events is challenging due to the spatial patterns, areal coverages, and genesis patterns of the events.

Flash floods inundate crops and other possessions. People have very little capacity to protect their crops and other resources. Additionally, affected people have very little knowledge about the adverse health consequences of flash floods. A pilot project was conducted in 2013 in Korchar Haor, Bangladesh, to develop an effective early warning system for flash floods by using a wireless sensor network (WSN) to provide residents of the area with a two-and-a-half to three-hour warning of the imminent arrival of a flash flood (Chowdhury and Hassan 2017).

Due to the topographical position of Bangladesh, conventional flood mitigation measures are not suitable in the country. Flood management practitioners have adopted a few structural approaches, such as establishing embankment and drainage systems, using low-level submersible embankments, evacuating unwanted rainwater, and providing drainage by pumping out accumulated water, to mitigate floods in Bangladesh (Sarker and Rashid 2013). Other strategies, for example, river dredging, reducing sand bars, and repairing river basins and embankments, have also been applied as structural flood management measures. Similarly, urban areas are protected by conventional practices such as constructed embankments and drainage systems, and pump-based drainage facilities (Haque 2016). Households usually build ponds and construct plinths around the banks of these pond as preventive measures against floodwater intrusion. In rural and coastal areas, school buildings and various community buildings are used as flood and cyclone shelters during natural hazards. People can use these shelters to save their lives and property (Chowdhury and Hassan 2017; Rahman and Salehin 2013). 


\subsection{Methods and Materials}

\subsubsection{Study Area}

Dhaka is purposively selected as an area of study because it is the largest administrative, commercial, and industrial center and the capital of Bangladesh (Bahauddin et al. 2014). A few rivers are located in Dhaka, such as the Buriganga, Turag, Tongi Khal, and Balu Rivers in its southwest, north, and east. Urban floods are a key challenge for urban areas in Asia (Gain et al. 2015). Like other cities, the megacity Dhaka also faces the problem of flash floods. The city is located between the latitudes $23^{\circ} 39^{\prime}$ and $23^{\circ} 54^{\prime} \mathrm{N}$ and the longitudes $90^{\circ} 20^{\prime}$ and $90^{\circ} 28^{\prime} \mathrm{E}$ (Fig. 12.1a). The specific study area is located in the northern part of Khilgoan Thana, between latitudes of $23^{\circ} 44^{\prime}$ and $23^{\circ} 47^{\prime} \mathrm{N}$ and between longitudes of $90^{\circ} 24^{\prime}$ and $90^{\circ} 27^{\prime} \mathrm{E}$. Ward number 03 was selected as the specific study area. The specific studied area is shown in Fig. 12.1b. This part of the city was selected because it is a flash flood-prone area that is not protected by an embankment or dam, and, almost every year, this area faces flash floods.

\subsubsection{Climatic Conditions}

Dhaka megacity lies in a subtropical monsoon climate zone. The region experiences six different seasons. From May to October, almost every year, Dhaka suffers from heavy rainfall due to a few key reasons, such as winter monsoon weather, early thunderstorms, and the summer season. Dhaka experiences an average of $2000 \mathrm{~mm}$

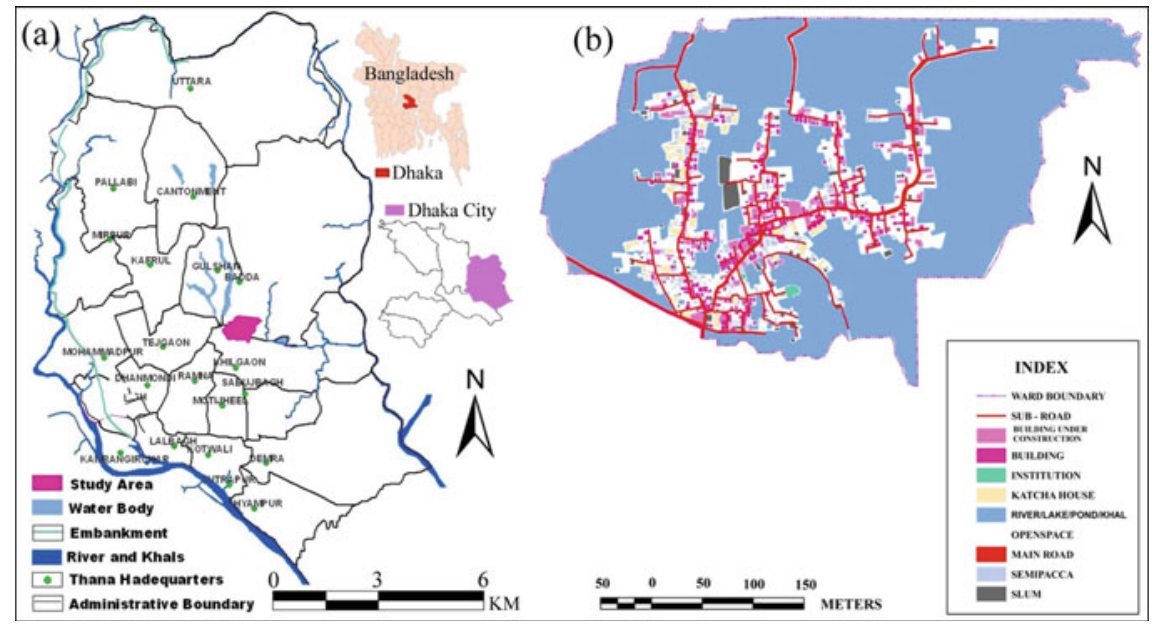

Fig. 12.1 a Map of the location of Dhaka megacity and $\mathbf{b}$ map of the specific study area 
of rainfall per year, and $90 \%$ of the rainfall occurs from May to October. Heavy downpours are common during the monsoon season. The highest temperatures rise to $42{ }^{\circ} \mathrm{C}$ in March and April, and the lowest temperatures reach $5{ }^{\circ} \mathrm{C}$ in December and January every year. The monthly precipitation of the area fluctuates from 80 to $130 \mathrm{~mm}$ (Rahman and Islam 2019). Table 12.1 shows the detailed climatic conditions of Dhaka megacity.

\subsubsection{Frequency of Devastating Floods}

Dhaka city dwellers are facing flash floods since long ago, and it is not a new threat for the residents. The city has been facing floods since its early stages. Historical data show that Dhaka city faced heavy floods in 1787 and 1788. During those floods, the streets were so inundated that the city's inhabitants continued their communications by boats within the city (Dewan et al. 2005). Again, in 1833-34, 1870 , the 1950s, and the 1960s, Dhaka and its adjacent areas were severely affected by floods. Similar situations occurred in 1954, 1955, 1970, 1974, 1980, 1987, 1988, 1998, 2004, and 2007 due to overflows of the rivers surrounding the city. Dhaka faced catastrophic floods in 1988 and 1998. The flood in 1988 was very remarkable among the floods in recent history due to its devastation; almost $60 \%$ of city dwellers were affected in $85 \%$ of the area of Dhaka city (Gain et al. 2015; Huq and Alam 2003; Masuya et al. 2015; Rahman and Islam 2019). The main flood-prone areas of Dhaka city are the low-lying areas of Motijheel, Badda, Jatrabari, Khilgaon, Baridhara, Shipahibag, and Sabujbag, where some commercial areas are also regularly inundated. Dhaka is recognized as a moderate- to very high-level flood-prone area. Only a small part $(8.04 \%)$ of the city is categorized as least vulnerable to flood hazards. On the other hand, $28.70 \%$ of greater Dhaka is highly vulnerable to flood hazards (Ahmed 2016). Among that 28.70\%, slum dwellers are most vulnerable because they often have low levels of education, economically poor, and living in marginal areas.

\subsubsection{Topography and Geological Conditions}

Dhaka lies at a low altitude in the Ganges Delta. The ground, which is flat and close to sea level, is characterized by tropical vegetation and moist soils. Dhaka is exposed to floods during the monsoon seasons due to heavy rainfall and cyclones and its position at the southern tip of the Madhapur tract. The city's core geomorphic units are the high terrain of Dhaka, the lowlands or floodplains, and newly built canals (Masood and Takeuchi 2012; Taylor 1849). The town and its surroundings are protected by two unique geological units, namely, Madhupur clays and alluvial accretion from the recent era. The Madhapur clays, which are ancient sediments, exposed due to standard topography and erosion around the city center. 


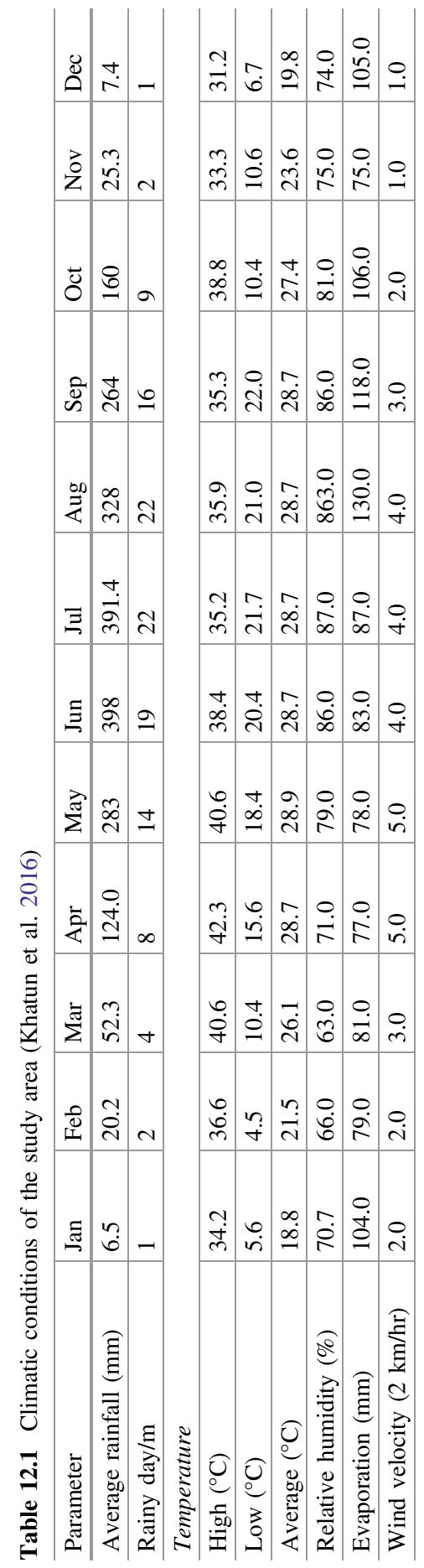


Other major topographic features of the city include the low-lying swamplands and marshlands situated within and around the city (Taylor 1840). Three individual bodies are seen at the subsurface level of the sedimentary chain and at a depth of $300 \mathrm{~m}$. The Domitila foundation of the Plio-Pleistocene period, consisting of medium to heavy sands and occasional gravels, is trickily shrouded by Madhupur clays. No surface folding is seen in the structures and lines of the city center. Additionally, N-S, E-W, NE-SW, and NW-SE patterns have been characterized by a significant number of faults and lineaments (Shams 1999; Sufia et al. 2009), which compose the major faults bordering the city.

\subsubsection{Data Collection and Analysis}

Data were gathered to fulfill the research objectives. Based on the surveyed literature, a questionnaire was created in this research to collect primary data. Before starting the questionnaire survey, a reconnaissance survey was carried out to understand the physical environment, human characteristics, settlement patterns, socioeconomic structures, and disaster history of the study area. During the survey, the real scenarios of the flood-prone lowlands (Fig. 12.2a) housing types (Fig. 12.2b), poor environmental conditions (Fig. 12.2c) and sanitation systems in the slum area (Fig. 12.2d) were captured. A questionnaire was developed for the collection of data after enough theoretical knowledge was obtained about the vulnerability to floods and the factors responsible for flood vulnerability. Then, the questionnaire was modified for the final survey. The factors responsible for flash floods include social factors, economic factors, structural factors, institutional factors, and environmental factors. Data were collected from a total of 300 households through the questionnaire survey. For the survey, the study area was selected purposively, and the surveyed households were selected by simple random sampling.

\subsubsection{Sampling Design}

Dhaka city and its eastern region were selected purposively. Ward number 3, part of Khilgoan Thana, was also selected purposively. This ward consists of 12,490 households (UNICEF 2009). It was impossible to survey all households in the ward. Therefore, with the ward map (Fig. 12.1b), 145 buildings were selected among the 311 buildings and 30 slum clusters were selected among the total 88 slum clusters by applying simple random sampling methods. The selected 145 buildings and 30 slum clusters contained 960 and 830 households, respectively. Among the total households, the sample size in this study was determined with the Kothari (2004) formula. Then, the households to be surveyed were selected by simple random sampling. The following table (Table 12.2) shows the sampling methods followed in the research. 

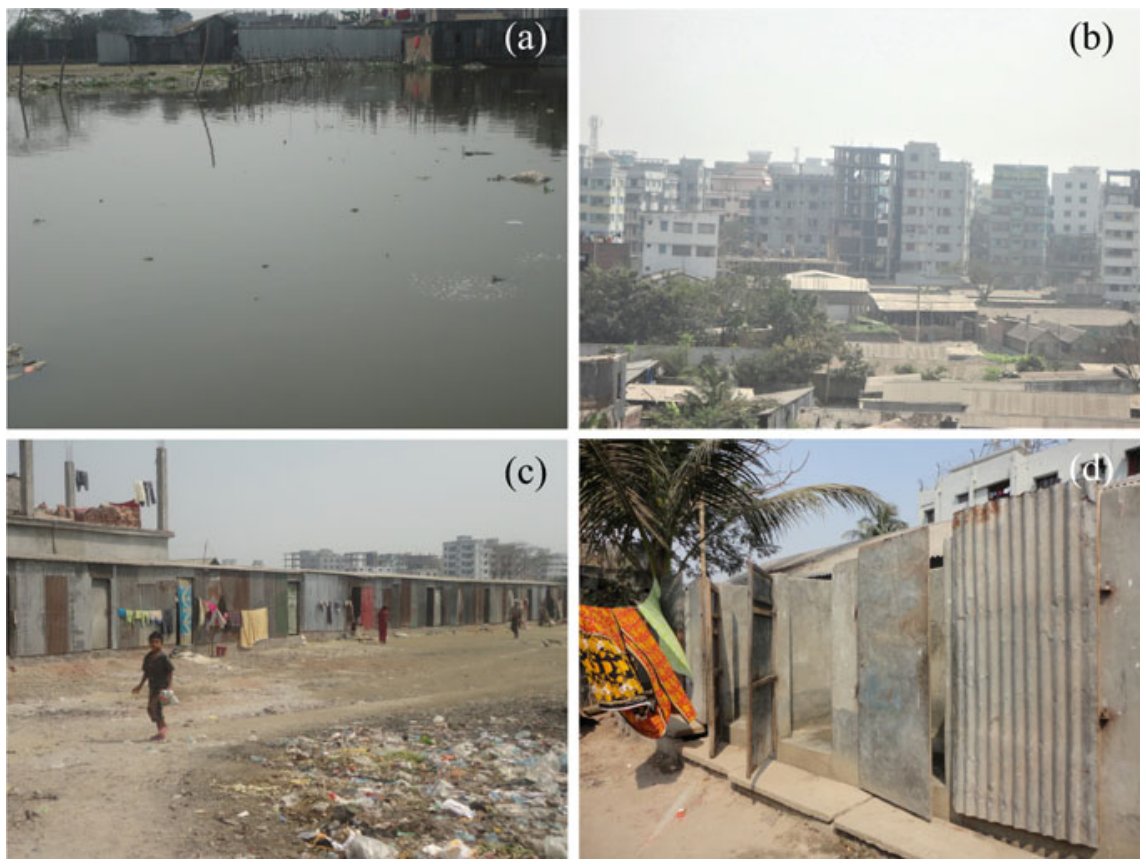

Fig. 12.2 Pictures of the study area captured during the survey: a flood-prone lowlands; b housing types; c, poor environmental conditions and $\mathbf{d}$ a sanitation system in a slum area

Table 12.2 Sampling statistics for the study area

\begin{tabular}{l|l|l|l|l}
\hline $\begin{array}{l}\text { Surveyed } \\
\text { part }\end{array}$ & Location & $\begin{array}{l}\text { Total number of } \\
\text { households }\end{array}$ & $\begin{array}{l}\text { Sample } \\
\text { size }\end{array}$ & $\begin{array}{l}\text { \% of total } \\
\text { households }\end{array}$ \\
\hline 30 clusters & Slum & 830 & 150 & $18.07 \%$ \\
\hline $\begin{array}{l}145 \\
\text { buildings }\end{array}$ & Non-slum & 960 & 150 & $15.62 \%$ \\
\hline Total & $\mathbf{2}$ & $\mathbf{1 7 9 0}$ & $\mathbf{3 0 0}$ & $\mathbf{1 6 . 8 5 \%}$ \\
\hline
\end{tabular}

\subsubsection{Determination of Sample Size}

There are multiple ways to determine the sample size. Time and money are matters of consideration in this regard. This study's sample size was determined based on Eq. 12.1 (Kothari 2004):

$$
n=\frac{z^{2} \times p \times q \times N}{e^{2}(N-1)+z^{2} \times p \times q}
$$


where $n=$ the sample size; $N=$ the size of the population; $e=$ the acceptable error; $p=$ the sample proportion; $q=1-p$; and $z=$ the value of the standard variant at a given confidence level.

In the slum area, total population $(N)=830$; the acceptable error $e=0.02$; the sample proportion $p=0.02 ; q=1-\mathrm{p}$; the value of a typical variant for the specified confidence level (95\%) was $z=1.96$; and the sample size, $n$, was calculated as follows.

$$
\begin{gathered}
n=\frac{1.96^{2} \times 0.02 \times(1-0.02) \times 830}{0.02^{2}(830-1)+1.96^{2} \times 0.02 \times(1-0.02)} \\
n=\frac{62.495}{0.331+0.075} \\
\mathbf{n}=153.928
\end{gathered}
$$

In the non-slum area, the total population $(N)=960$; the acceptable error $e=0.02$; the sample proportion $p=0.02 ; q=1-p$; and the value of a typical variant for the specified confidence level (95\%) was $z=1.96$; sample size, $n$, was calculated as follows.

$$
\begin{gathered}
n=\frac{1.96^{2} \times 0.02 \times(1-0.02) \times 960}{0.02^{2}(960-1)+1.96^{2} \times 0.02 \times(1-0.02)} \\
n=\frac{72.283}{0.383+0.075} \\
\mathbf{n}=157.832
\end{gathered}
$$

Finally, sample sizes of 150 for both the slum and non-slum areas were determined for the questionnaire survey. The total percentages of the sample sizes relative to the total number of slum and non-slum households were $16.85 \%$ and $18.07 \%$, respectively (Table 12.2 ).

After editing and coding, collected data were given as input to a computer. Then, all the data were analyzed distinctly. The spatial data were investigated with Arc/GIS 9.3, and the temporal data were analyzed using statistical computer software with Statistical Software for Social Sciences (SPSS). Finally, both types of analyzed data were presented as maps, tables, and graphs. Figure 12.3 reveals the main steps of the research methodology. 


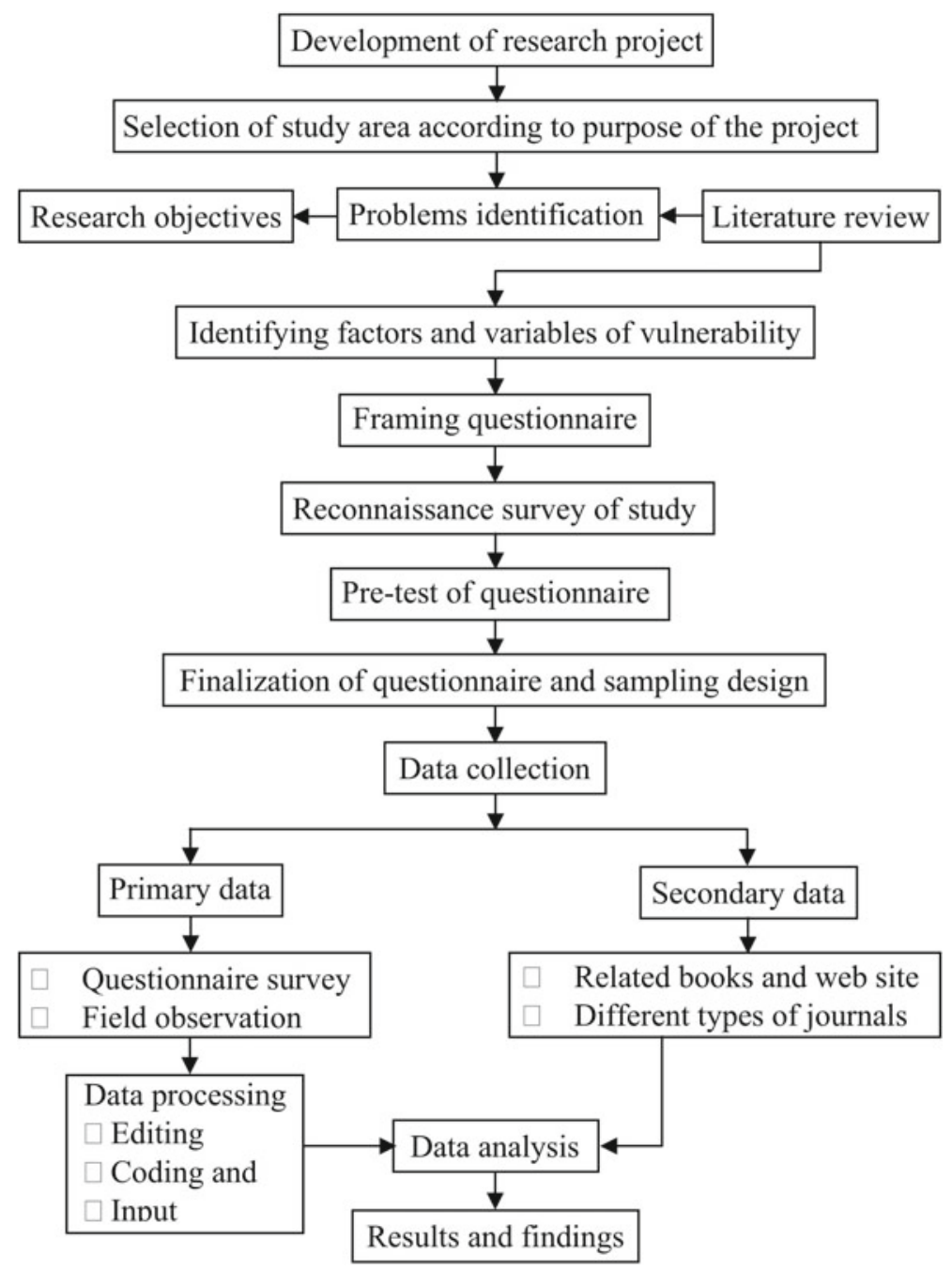

Fig. 12.3 Flow chart of the research methodology of this study

\subsubsection{Methods for Vulnerability Mapping}

In this study, the five considered factors were assigned weights from 1 to 9 by Saaty's (2008) rating scale (Table 12.3). There is no specific rule for the comparison of factors; therefore, it was considered that the social factor is more important due to its significant consequences for flash floods. Hence, social vulnerability was given a weight of 9 . There were five identified factors that affect the vulnerability of a household to flash floods. Economic vulnerability is considered a very much more 
important factor for flash floods than structural vulnerability. Therefore, a weight of 7 was allocated for the economic factor, and a weight of 5 was assigned for the structural factor. The environmental factor has less influence on flash flood vulnerability; thus, its weight was defined as 2 . Likewise, it was quantified that institutional vulnerability is more important than the environmental factor in influencing household vulnerability to flash floods. A value of 3 was assigned for institutional vulnerability. Table 12.3 exhibits the assigned weights of all factors.

A normalization function (Eq. 12.2) was used to rearrange the factors' vulnerability scores as follows:

$$
\text { Normalized output }=\frac{\text { input }- \text { minimal value }}{\text { maximal value }- \text { minimal value }},
$$

First, this normalization function was applied to all five factors. The individual factors' median values were used to shift the output away from 0 (Eq. 12.3).

$$
\text { Updated variable }=\text { normalized variable }+ \text { median of variable. }
$$

Therefore, all factors had a central tendency near 1 . The index was again normalized and multiplied by 100 to obtain an output between 0 and 100 .

\subsection{Results}

\subsubsection{Measuring Social Vulnerability}

Measuring social vulnerability to flash floods is a vital step for measuring the overall vulnerability of the community. Social vulnerability to flash floods is mostly evident after a hazard event has occurred (de Moor et al. 2018; Dintwa et al. 2019; Emrich and Cutter 2011; Huq et al. 2020a). The aims of measuring social vulnerability are to recognize and understand the populations that are very vulnerable and susceptible to the influences of flash floods.

\subsubsection{Education and Occupation}

Flash floods turn into flood disasters not only due to inundation of the land but also due to the vulnerability of a population based on certain socioeconomic circumstances. Poor education is one of these circumstances that is partly responsible for the flood vulnerability of urban inhabitants. Households with higher-educated members are less vulnerable to flash floods than households including members with lower education levels (Huang et al. 2012; Mavhura et al. 2017). Flash floods are serious natural hazards in Dhaka, Bangladesh. People living in slums in this area also have lower levels of education (Huq et al. 2020b). These low-educated people 
Table 12.3 Assigned weights of the influencing factors (Saaty 2008)

\begin{tabular}{l|l|l}
\hline No & Theme & Assigned weight \\
\hline 1 & Social & 9 \\
\hline 2 & Economic & 7 \\
\hline 4 & Structural & 5 \\
\hline 5 & Institutional & 3 \\
\hline 6 & Environmental & 8 \\
\hline
\end{tabular}

$1,3,5,7$, and 9 indicate equal, more, much more, very much more, and absolutely more important, respectively, while $2,4,6,8$ indicate intermediate values. Saaty's pairwise rating scale was followed for this assessment

migrate from villages to the city to seek jobs and better lives. They also mainly rely on informal jobs for their daily foods. As a result, they are extremely vulnerable to the flash floods that commonly occur in the area. Most of the survey respondents in the slum area (approximately 46.7\%) had no formal academic education, while $36 \%$ of the respondents had primary-level educations, and only $6 \%$ of respondents' educational levels were Secondary School Certificate (SSC) or Higher Secondary Certificate (HSC). The remaining $11.3 \%$ of respondents' educational qualifications ranged from class five to class ten (Table 12.4). In the surveyed slum clusters, no residents were found to have a bachelor's or master's degree. Table 12.4 also shows that in the non-slum area, approximately half (nearly $48.7 \%$ ) of the respondents had bachelor's or master's degrees, and $42.7 \%$ of the respondents' educational levels were SSC or HSC. Only $2 \%$ of these respondents were illiterate, $4 \%$ had primary educations, and $2.7 \%$ had class-ten educations.

Occupations can be directly related to hazards. For example, some workers become jobless during floods (Huq and Hossain 2012). Paavola (2008) demonstrated that job diversity and different income sources allow people to build stable livelihoods and cope with various risk issues; therefore, with diversified income sources, risks (e.g., those created by flash floods or climate change) could be controlled and recovered easily and quickly. Among the poorest day laborers, construction workers and rickshaw pullers are most vulnerable to flash floods. In slum areas, most people are normally engaged with informal activities such as rickshaw pulling, day labor, petty businesses, and small job services. From the empirical data (Table 12.4), it can be observed that the most common occupation for household heads in the slum area was day labor (approximately 46.0\%). These day laborers worked in restaurants, factories, hawking rings, bus drivers, and so on. However, in the studied slum clusters, the occupation of many household heads was rickshaw pulling (approximately 28.7\%). Nearly $8.7 \%$ of the surveyed household heads had no job, and $10.0 \%$ of the household heads were engaged with petty business. The remaining approximately $3 \%$ of household heads were homemakers. In the non-slum area, about $50.7 \%$ of household heads were engaged with the service sector (government, private, etc.). Of the household heads in the non-slum 
Table 12.4 Distribution of respondents' educational qualifications and occupations

\begin{tabular}{l|c|l|l|l|c}
\hline \multicolumn{2}{l}{ Education } & \multicolumn{2}{l}{ Occupation } \\
\hline $\begin{array}{l}\text { Educational } \\
\text { qualification }\end{array}$ & Slum & Non-slum & $\begin{array}{l}\text { Type of } \\
\text { occupation }\end{array}$ & Slum & Non-slum \\
\cline { 4 - 6 } & & & Percent & Percent \\
\cline { 5 - 7 } & Percent & Percent & Service & 00 & 50.7 \\
\cline { 5 - 7 } & & & Business & 10.0 & 32.7 \\
\hline Illiterate & 46.7 & 2.0 & Homemaker & 2.7 & 9.3 \\
\hline$>1<5$ & 36.0 & 4.0 & Unemployment & 8.7 & 7.3 \\
\hline$>5<10$ & 11.3 & 2.7 & Rickshaw-puller & 28.7 & 00 \\
\hline SSC and HSC & 6.0 & 42.7 & Day-labor & 46.0 & 00 \\
\hline Bachelor and Masters & 00 & 48.7 & Housemaid & 4.0 & 00 \\
\hline Total & $\mathbf{1 0 0 . 0}$ & $\mathbf{1 0 0 . 0}$ & Total & $\mathbf{1 0 0 . 0}$ & $\mathbf{1 0 0 . 0}$ \\
\hline
\end{tabular}

area, $30 \%$ were businesspeople, more than $9 \%$ were homemakers, and $7.3 \%$ were unemployed (Table 12.4). From the above data, an evident discrepancy between the levels of education of people living in the slum area and people living in the non-slum area can be observed. Most of the non-slum habitants were engaged with formal professions. In contrast, few dwellers of the slum area were involved with the formal sector. These low-paying jobs cause residents of the slum area to be more vulnerable to flash flood hazards, and any kind of hazard or disaster, than non-slum people.

\subsubsection{Gender}

Gender inequality was also widespread in the study area, as women normally cannot go outside for earnings. Moreover, women feel unsafe when men temporarily travel to other places, leaving them at home (Kamal et al. 2018). For this reason, women tend to be socially vulnerable due to their social environment. The experimental field observation data showed that the male-female ratio was almost the same irrespective of area. Out of the surveyed people living in the slum area, about $51.9 \%$ (based on the questionnaire survey) were male, and $48.1 \%$ were female. In the non-slum area, approximately $50.7 \%$ (based on the results of the questionnaire survey) were male, and the remaining $49.3 \%$ were female (Table 12.5). The vulnerability levels of the residents of studied slum and non-slum areas were almost the same in consideration of gender.

\subsubsection{Age Structure}

Elderly individuals and children are generally considered as vulnerable groups (Cutter et al. 2003). Additionally, some studies have directly used elderly individuals to assess vulnerability because they live alone (Huq and Hossain 2015). The 
Table 12.5 Gender distribution of residents of the slum and non-slum areas

\begin{tabular}{l|l|l|l|c}
\hline \multirow{2}{*}{ Type of household head } & \multicolumn{3}{|l|}{ Slum } & Non-slum \\
\cline { 2 - 5 } & Frequency & Percent & Frequency & Percent \\
\hline Male & 387 & 51.9 & 322 & 50.7 \\
\hline Female & 359 & 48.1 & 313 & 49.3 \\
\hline Total & $\mathbf{7 4 6}$ & $\mathbf{1 0 0 . 0}$ & $\mathbf{6 3 5}$ & $\mathbf{1 0 0 . 0}$ \\
\hline
\end{tabular}

present study followed the method of Sebald (2010) to show vulnerability due to age. In the Bangladesh context, this study categorized the age groups as $0-18$ years, 18-55 years, and above 55 years for both the slum and non-slum areas. From Fig. 12.4, it seems that in the slum area, the active age covered $53.9 \%$ of all surveyed household members in slum clusters (based on a questionnaire survey). Of the remaining surveyed individuals, $41.8 \%$ were inactive groups (i.e., children) and $4.3 \%$ were elderly individuals. Figure 12.4 also shows that in the non-slum area, the dominant age group was the active group, encompassing nearly $58.0 \%$ of the total household members; $36.2 \%$ were in the inactive group, and the remaining $5.8 \%$ were elderly individuals. These age groups are more vulnerable to flood disasters because they are dependent on others. The age group comprising individuals above 55 years is more vulnerable than all other age groups because these individuals are physically unable to move into safe areas during floods and to collect relief from relief distributors. The number of elderly persons was greater in the non-slum area than in the slum area, but the number of inactive people was greater in the slum area (41.8\%) than in the non-slum area (36.2\%). From this viewpoint, it can be said that people living in slums are less vulnerable than those living in non-slums.

\subsubsection{Existence of Disable Persons}

The presence of a disabled person makes a family vulnerable to hazards. This variable is significantly responsible for creating flood vulnerability because during a flash flood event, sensible and physically fit people cannot move easily. Thus, people with disabilities cannot move to safe places without the help of others. Therefore, disability is a vital cause that can increase the vulnerability of a family. The study found that in the slum area, approximately $20 \%$ of households had disabled persons, whereas more than $80 \%$ of households did not. In contrast, in the non-slum areas, more than $10 \%$ of households contained disable persons, while around $90 \%$ of households had no disabled persons (Fig. 12.5). 

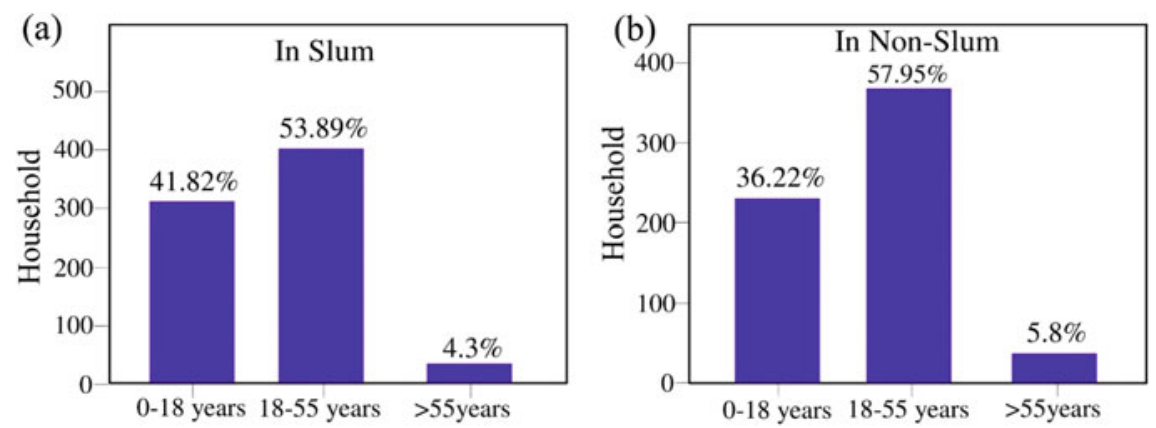

Fig. 12.4 Age structure of the urban inhabitants a the studied slum area and $\mathbf{b}$ the studied non-slum area
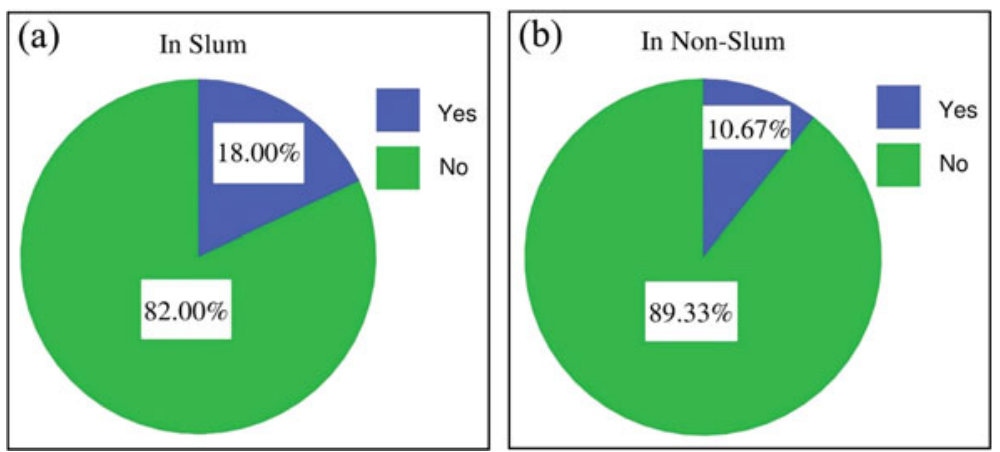

Fig. 12.5 Existence of disable persons in $\mathbf{a}$ the slum area and $\mathbf{b}$ the non-slum area

\subsubsection{Preparation}

Low awareness of and preparedness for natural disasters cause vulnerability (Bouzelha et al. 2018). Many criteria can be included to identify the preparedness level of a household or community for facing future flood hazards or any kind of hazard. The present study selected reserves of dry food at the household level to evaluate the preparedness level of the households. Food scarcity is common for slum dwellers because their livelihood resources are very limited (Pham et al. 2019). In Dhaka city, residents of the slum area who have no good jobs and poor access to other resources are faced food scarcities. Table 12.6 shows that in the slum area, most households $(80.7 \%)$ had no food reserves to consume during a flash flood, and only $19.3 \%$ of households kept dry food. In contrast, all inhabitants of the non-slum area (of the surveyed households) kept dry food to consume on disaster days. Most of the slum dwellers were not aware of or prepared for tackling any type of misfortune. Therefore, residents of the slum area are more vulnerable than residents of the non-slum area to the destructive hazards of flash floods or cyclones. 
Table 12.6 Reserves of dry food

\begin{tabular}{l|l|l|l|l}
\hline \multirow{2}{*}{ Reserve status of dry food } & Slum & Non-slum & \multicolumn{2}{l}{} \\
\cline { 2 - 5 } & Frequency & Percent & Frequency & Percent \\
\hline Yes & 29 & 19.3 & 150 & 100 \\
\hline No & 121 & 80.7 & 00 & 00 \\
\hline Total & $\mathbf{1 5 0}$ & $\mathbf{1 0 0 . 0}$ & $\mathbf{1 5 0}$ & $\mathbf{1 0 0 . 0}$ \\
\hline
\end{tabular}

\subsubsection{Social Network}

The ability of a household to recover from a disaster can reduce the vulnerability of the household. Social networks are the main influencing factor that strengthens the adaptive ability of a household (Few and Tran 2010). The power of resilience depends on social or neighborhood networks (Huq 2017). Several organizations help people lead their livelihoods smoothly, such as laborer's unions and women's unions. The members of these organizations can receive useful information associated with current news, such as information on natural disasters (flash floods). Simultaneously, the involvement of residents with these groups also helps them to create closer social bonds with other societies and people, thus, facilitating residents to seek support or help during a crisis. In Dhaka megacity, people mostly receive this kind of assistance from local governmental organizations. This service is not enough, but it has contributed slightly in lessening the impacts of natural hazards on households.

Furthermore, in Bangladesh, particularly Dhaka city, the social network may be an operative channel used to obtain new information and pursue common support, for instance, work sharing. Similarly, people can look for support (getting loans or labor) from their families or neighbors within their communities (Huq and Hossain 2015); this factor was chosen in this study as a criterion used to evaluate the social network of an area. That is, in times of financial emergency, where do residents go for rescue? Social capital refers to mutual support among neighbors, family members' assistance, and widespread social networks. It is a vital safety net that vulnerable households can use to cope with flash floods (Gain et al. 2015). Table 12.7 shows that in the slum area, nearly $40.7 \%$ of household heads go to their relatives living in Dhaka to remedy their financial problems. Approximately, one-fourth of household heads (roughly 24.0\%) go to their neighbors to solve their financial problems. The remaining 12.7, 4.0, and $11.3 \%$ of household heads go to their relatives living beyond Dhaka, to the bank, and to NGOs, respectively. Among the total non-slum households, nearly one-fourth of household heads (around $26.7 \%$ ) go to their relatives living in Dhaka to meet their financial problems, and more than one-third of household heads (approximately 36.7\%) go to their relatives living beyond Dhaka to solve their financial problems. The remaining 3.3, 20.0, and $13.3 \%$ of household heads go to their neighbors, banks, and NGOs, respectively, for financial help (Table 12.7). These results demonstrate an interesting matter: very few non-slum dwellers go to their neighbors to solve their financial problems. 
Table 12.7 Sources of financial help

\begin{tabular}{l|l|l|l|l}
\hline \multirow{2}{*}{ Sources of help } & \multicolumn{2}{l|}{ Slum } & Non-slum & \\
\cline { 2 - 5 } & Frequency & Percent & Frequency & Percent \\
\hline Relatives (Dhaka) & 61 & 40.7 & 40 & 26.7 \\
\hline Relatives (beyond Dhaka) & 19 & 12.7 & 55 & 36.7 \\
\hline Neighbors & 36 & 24.0 & 5 & 3.3 \\
\hline Bank & 6 & 4.0 & 30 & 20.0 \\
\hline NGO & 17 & 11.3 & 20 & 13.3 \\
\hline Local loan agency & 11 & 7.3 & 00 & 00 \\
\hline Total & $\mathbf{1 5 0}$ & $\mathbf{1 0 0 . 0}$ & $\mathbf{1 5 0}$ & $\mathbf{1 0 0 . 0}$ \\
\hline
\end{tabular}

The condition of the social network of slum dwellers was found to be much better than that of non-slum dwellers.

\subsubsection{Measuring Economic Vulnerability}

\subsubsection{Income}

People of different income groups are affected by flash floods (Huq 2013). Additionally, a resident who makes money from different sources holds more adaptive capability than a resident who earns money from limited income sources (Abdul-Razak and Kruse 2017). The incomes of urban dwellers mainly rely on business or formal jobs, not on agricultural farming. Thus, during unexpected flash floods, people can become extremely vulnerable to losses of income and livelihood assets (Kamal et al. 2018). Therefore, to show the vulnerability of slum and non-slum dwellers, this study categorized the income levels of slum and non-slum dwellers differently; to quantify the vulnerability level of each group, the number of classes was uniform. In the surveyed slum areas, the highest monthly household income was 52,000 BDT, and the lowest was 3500 BDT. In the slum area surveyed, nearly $9 \%$ of the total samples belonged to the lowest income group, with monthly income values between 3500 and 5500 BDT. The largest number of households' (almost $23.3 \%$ of all surveyed households) monthly income values were between 7501 and 9500 BDT, while 16.0 and $14.7 \%$ of households' monthly total income values were between 5501-7500 BDT and 11,501-13,500 BDT, respectively. Approximately, $15.3 \%$ of households earned more than 15,500 BDT per month. The remaining 14.0 and $8.0 \%$ of households had monthly income levels between 9501-11,500 BDT and 13,501-15,500 BDT, respectively (Fig. 12.6). In the non-slum area, the highest monthly household income was 125,000 BDT, and the lowest was 12,000 BDT. The surveyed field data of the non-slum area portrayed that more than one-fourth (approximately 26.7\%) of the households had monthly income levels above 42,000 BDT. Around 16.0\% of the households' monthly 

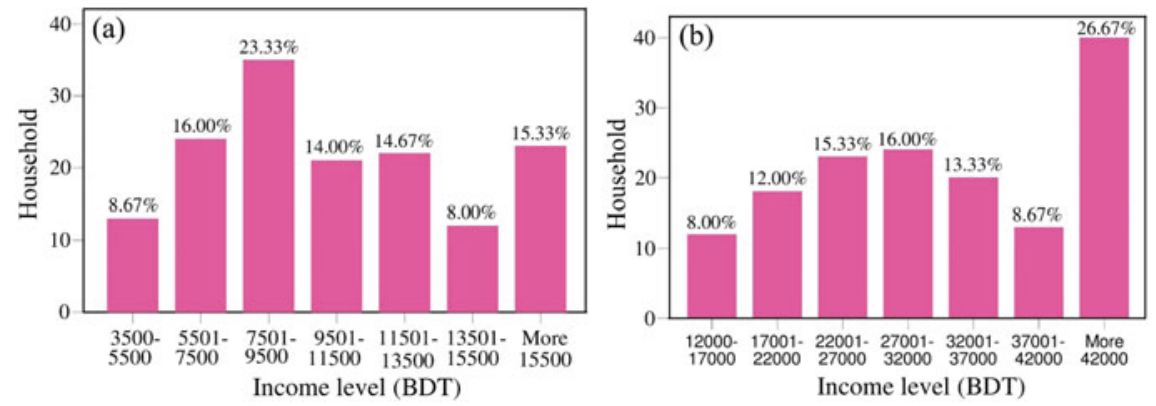

Fig. 12.6 Monthly household income levels

income values were between 27,001 and 32,000 BDT, while 15.3 and $13.3 \%$ of the households' monthly income levels were between 22,001-27,000 BDT and 32,001-37,000 BDT, respectively. Approximately, 8.0 and 12.0\% of households earned 12,000-17,000 BDT and 17,001-22,000 BDT monthly (Fig. 12.6). It seems that slum dwellers are much more vulnerable to any crisis than non-slum dwellers are in terms of income.

\subsubsection{Housing Land Ownership and Savings}

Land ownership, or the lack thereof, is another factor responsible for creating vulnerability. It is the key aspect affecting the vulnerability levels of different social groups. Land ownership for housing is vital for people to confirm their livelihoods since it is considered one of the basic needs for humans and increases landowners' incentives for investment in long-term development (Amoako and Inkoom 2018). Additionally, owning land is a significant asset that can aid in obtaining a loan from microfinance organizations. Land ownership assists households in ensuring food safety as landowners have wealth to invest. Incidentally, the surveyed households in the slum area had no percentage of land ownership, which is a leading cause affecting their vulnerability levels. Poor urban households often have no land ownership for housing. Thus, these households are highly vulnerable. The surveyed data showed that members of each household in the slum area were living as tenants.

In the non-slum area, only $29.3 \%$ of those interviewed, owned their land for housing, while most (approximately 70.7\%) did not own land for housing. The majority of those interviewed lived as tenants or in relatives' houses (Table 12.8). Moreover, the savings of a household can be used to determine the power of resilience of the household (Sarker et al. 2020). Usually, slum dwellers cannot afford to keep any savings with which to face future calamity because of their poverty levels. Table 12.8 reveals that in the slum area, only $24.7 \%$ of households had savings to face disaster days, whereas most (above $75 \%$ ) of the households had 
Table 12.8 Land ownership (housing)

\begin{tabular}{|c|c|c|c|c|}
\hline \multirow[t]{2}{*}{ Status } & \multicolumn{2}{|l|}{ Slum } & \multicolumn{2}{|l|}{ Non-slum } \\
\hline & $\begin{array}{l}\text { Land ownership } \\
(\%)\end{array}$ & $\begin{array}{l}\text { Savings status } \\
(\%)\end{array}$ & $\begin{array}{l}\text { Land ownership } \\
(\%)\end{array}$ & $\begin{array}{l}\text { Savings status } \\
(\%)\end{array}$ \\
\hline Yes & 00 & 24.7 & 29.3 & 92.0 \\
\hline No & 100.0 & 75.3 & 70.7 & 8.0 \\
\hline Total & 100.0 & 100.0 & 100.0 & 100.0 \\
\hline
\end{tabular}

no savings to face calamity. Most (approximately 92\%) of the non-slum households saved money for the future and kept their savings in various places, such as banks, post offices, NGOs, and with relatives. Only $8 \%$ of households in the non-slum area had no savings (Table 12.8). In terms of land ownership, people living in slum areas are more vulnerable than people living in non-slum areas. Inhabitants of slum areas cannot save money due to their economic crises, lack of income sources, and high expenditures.

\subsubsection{Insurance}

Having health, house, flood, or vehicle insurance can reduce the vulnerability of a household to hazards (Dintwa et al. 2019). The serious sickness of a family member is a key concern for the other members of a household because it influences their morale and spirits. Sicknesses also affect a family's economic standing, as sicknesses are unwanted and extensively influence consumption and wages. It has two important financial/economic impacts: extra expenditures for treatment and medical services and income drops owing to labor deficiencies. Sicknesses increase the poverty levels of low-income households and push the household members to poor health due to unforeseen costs.

These consequences cause the exposure of households to natural hazards in developing countries due to these households having almost no health insurance. Those seeking care from the Health Ministry of Bangladesh without health insurance might face significant difficulties and high-cost medical services and health care (Andaleeb et al. 2007). The data obtained from the survey regarding insurance express that the insurance scenarios in the slum area are reversed from those in the non-slum area. In the slum area, only $19.3 \%$ of households had insurance, while $80.67 \%$ had no insurance. Here, insurance means any type of insurance in any format, including health insurance, vehicle insurance, fire insurance, etc. In the non-slum area, a greater number (almost 72.7\%) of households had insurance, and the remaining $27.3 \%$ had no insurance (Fig. 12.7). It can be concluded that slum dwellers have poor savings and insurance levels due to their poverty levels. Many members of the population living without health insurance or any other type of insurance causes the community to be highly vulnerable to flash floods. 

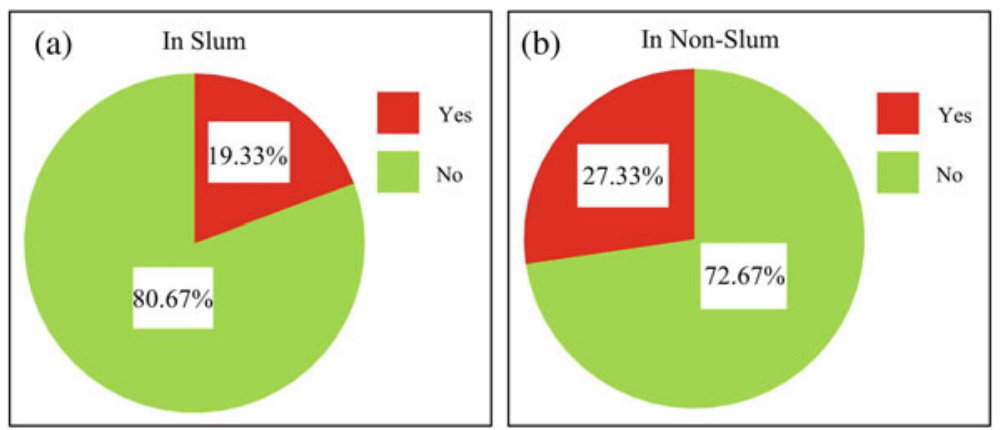

Fig. 12.7 Insurance statuses for a individuals living in the studied slum area and $\mathbf{b}$ those living in the studied non-slum area

\subsubsection{Vehicle Ownership}

In hazardous and disastrous situations, cars or other vehicles are very useful for relocating from a dangerous place to a safe place. Those who own a vehicle that can be used for moving makes them less vulnerable than those who have no personal vehicle. Therefore, the present study selected ownership of vehicle as a variable of vulnerability. The surveyed empirical data show that in the slum area, most (almost $88 \%$ ) of the surveyed household heads did not own vehicles, and only $12 \%$ of households had bicycles or rickshaws. In the non-slum area, most (about 57.3\%) of the households had no vehicle, while approximately $32 \%$ had motorcycles. The remaining 7.3 and $3.3 \%$ of households had private cars and bicycles, respectively (Table 12.9). Due to the unavailability of vehicles, both slum and non-slum habitats are vulnerable to flash floods.

\subsubsection{Measuring Structural Vulnerability}

Structural factor also affects the vulnerability of people to flash floods. The types of housing, shelter availability, road networks, transportation systems, existing evacuation roads, embankments to protect from floods, drainage density, and

Table 12.9 Ownership of vehicles

\begin{tabular}{l|l|l|l|c}
\hline \multirow{2}{*}{$\begin{array}{l}\text { Types of } \\
\text { vehicle }\end{array}$} & \multicolumn{3}{|l|}{ Slum } & Non-slum \\
\cline { 2 - 5 } & Frequency & Percent & Frequency & Percent \\
\hline Motorcycle & 00 & 00 & 48 & 32.0 \\
\hline Private car & 00 & 00 & 11 & 7.3 \\
\hline Bicycle & 18 & 12.0 & 5 & 3.3 \\
\hline Nothing & 132 & 88.0 & 86 & 57.3 \\
\hline Total & $\mathbf{1 5 0}$ & $\mathbf{1 0 0 . 0}$ & $\mathbf{1 5 0}$ & $\mathbf{1 0 0 . 0}$ \\
\hline
\end{tabular}


geographical positions in an area are typically considered to be variables/indicators of structural vulnerability. Four key variables: housing types, shelter availability, road networks, and transportation systems were selected in this study to assess the structural vulnerability of households to flash floods in Dhaka megacity.

\subsubsection{Housing Quality}

Housing quality is one of the most important variables of structural factors. It can increase or decrease the level of flash flood vulnerability of a household. The structure of a house and its physical location significantly influence to spread of the hazard impacts. For example, households located along rivers are susceptible to flash floods (Adelekan 2011). A building can be situated in a flash flood hazard zone, but developing its structure can reduce its vulnerability (Zakour and Swager 2018). The surveyed data show that approximately $75.3 \%$ of slum households lived in kutcha ${ }^{1}$ houses, while only $24.7 \%$ lived in semi-pucca ${ }^{2}$ houses. Figure $12.8 \mathrm{a}, \mathrm{b}$ shows the housing types in the study area. Table 12.10 reveals that no surveyed residents in the non-slum area lived in semi-pucca or kutcha houses. All the surveyed residents of the non-slum area were living in pucca ${ }^{3}$ houses. It is obvious that fragile housing types make slum dwellers more vulnerable to flash floods. The findings of Braun and Aßheuer (2011) revealed that approximately 50\% of respondents narrated a flash flood that hit them severely and reached above 2.5 feet inside their living rooms. Their residences remained inundated with floodwaters for half a month. Moreover, the floodwaters remained adjacent to their homes for nearly a month.

\subsubsection{Sheltering During Flash Flood Events}

The sheltering system is another variable responsible for influencing vulnerability. People who go to shelters during flash floods are less vulnerable than those that do not. The government and NGOs provide sheltering facilities. Therefore, the people who go to these shelters are much more secure than those who do not. The field data disclose that more than $55 \%$ of slum households have gone to shelters during floods, while $44.7 \%$ of households have not gone to shelters during floods. Only approximately $24 \%$ of non-slum household members went to shelters during a catastrophic flood, such as the 1998 flood, and the remaining 76\% of household members did not go to shelters during floods (Fig. 12.9). Braun and Aßheuer (2011) also found that almost $50 \%$ of surveyed households were compelled to give up their homes and take shelter in government schools on elevated roads, or at

\footnotetext{
${ }^{1}$ Walls made by tin, lightwood, bamboo or plastic; straw or tin roof materials.

${ }^{2}$ Walls made by brick of metallic structure; tin roof material.

${ }^{3}$ Walls made by brick; concrete slab or cement tiles roof materials.
} 


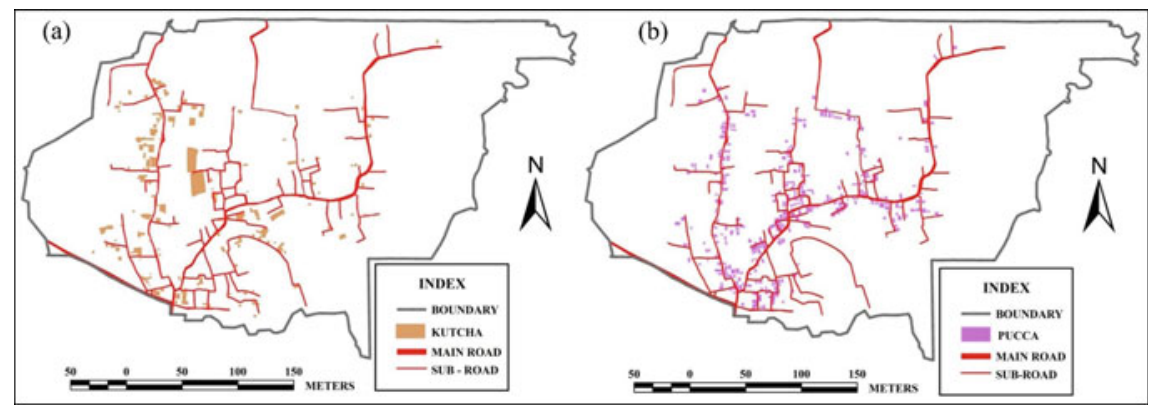

Fig. 12.8 a Kutcha houses and b pucca houses in the study area

Table 12.10 Housing type of study area

\begin{tabular}{l|l|l|l|l}
\hline \multirow{2}{*}{ Housing type } & \multicolumn{2}{|l|}{ Slum } & Non-slum \\
\cline { 2 - 5 } & Frequency & Percent & Frequency & Percent \\
\hline Pucca & 00 & 00 & 150 & 100 \\
\hline Semi-Pucca & 37 & 24.7 & 00 & 00 \\
\hline Kutcha & 113 & 75.3 & 00 & 00 \\
\hline Total & $\mathbf{1 5 0}$ & $\mathbf{1 0 0 . 0}$ & $\mathbf{1 5 0}$ & $\mathbf{1 0 0 . 0}$ \\
\hline
\end{tabular}

relatives' houses or dams. Sheltering places do not always provide better facilities than housing; this is why non-slum dwellers are reluctant to go to shelter places. Slum dwellers keep fewer assets in their houses and thus can move easily in disastrous situations and go to sheltering places.

\subsubsection{Road Network}

Road networks play a great role in affecting household vulnerability to flash floods. With a dilapidated road network, people cannot move easily in a normal situation. The study area's road network is not good (Fig. 12.10a); the existing roads are narrow and clumsy. Additionally, in the slum area, approximately $52.7 \%$ of respondents thought that their locality's existing road network was not good. Above $30 \%$ of the total respondents mentioned that the road network was good. More than $16 \%$ of respondents believed that the area's road network was very bad (Fig. 12.10b). However, approximately $41.3 \%$ of respondents in non-slum areas noted that the existing road network was not good because they lived away from the main roads. In contrast, $52.7 \%$ of respondents lived near the main road, so they thought that the existing road was good, and the remaining $6 \%$ of respondents indicated that the existing road network was very bad (Fig. 12.10c). 

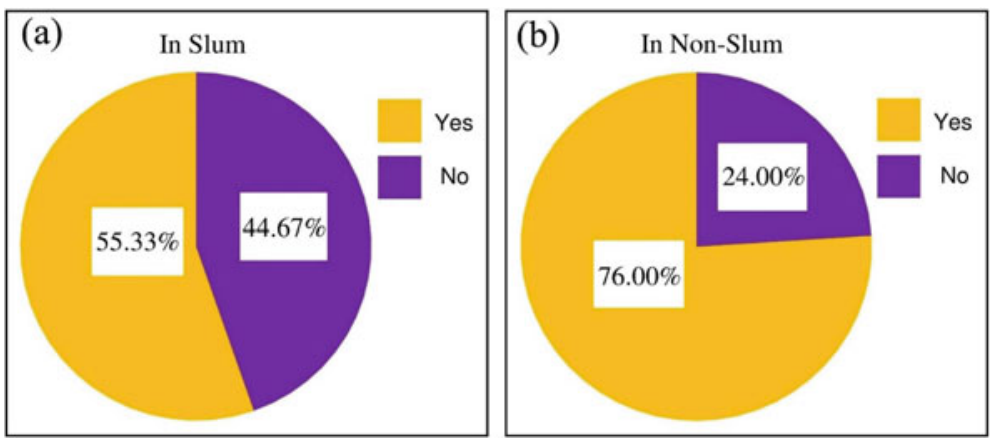

Fig. 12.9 Sheltering during floods: a the percentage of people living in the studied slum area who went to shelters during flash floods; $\mathbf{b}$ the percentage people living in the studied non-slum area who went to shelters during flash floods

\subsubsection{Transportation System}

The transportation system is another significant structural variable affecting household vulnerability to flash floods. Table 12.11 exhibits that $47.3 \%$ of respondents living in the slum area thought that the transportation system was not good, although more than $35 \%$ of respondents thought that the transportation network was good. Only $17.3 \%$ of respondents believed that the transportation system was very bad. Nearly $62.7 \%$ of those interviewed in the non-slum area felt that the transportation system was good, but $30 \%$ believed that the transportation system was not good. The remaining $7.3 \%$ of respondents indicated that the transportation system was very bad (Table 12.11). Due to the uneven road network and poor transportation services, people living in both the slum and non-slum areas are vulnerable to flash floods.

\subsubsection{Institutional Vulnerability}

The institutional setup of a community can significantly influence the vulnerability of the community to flash floods (Huq 2017). The presence of an emergency management committee can help to reduce vulnerability during a disastrous situation. The major institutional vulnerability factors are early warning systems, services for emergency situations, and governance. In this study, only two variables (aid during floods and warning before floods) were considered when estimating people's vulnerability levels to flash floods. 

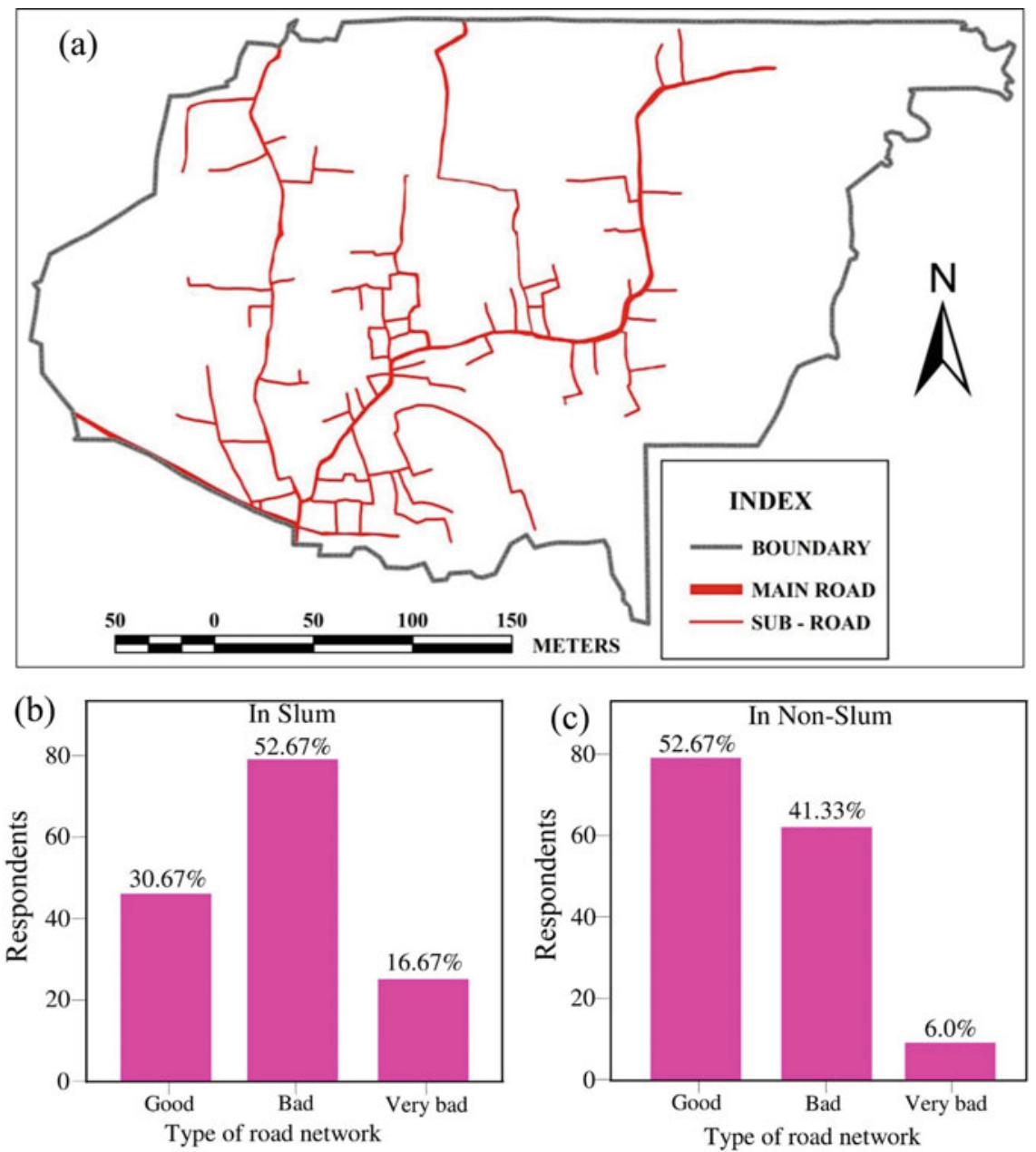

Fig. 12.10 a Condition of the road network in the study area; $\mathbf{b}$ and $\mathbf{c}$ respondents' opinions about the road network in the study area

Table 12.11 Condition of the transportation system

\begin{tabular}{l|l|l|l|c}
\hline \multirow{2}{*}{ Transportation system } & Slum & Non-slum & \\
\cline { 2 - 5 } & Frequency & Percent & Frequency & Percent \\
\hline Good & 53 & 35.3 & 94 & 62.7 \\
\hline Not good & 71 & 47.3 & 45 & 30.0 \\
\hline Very bad & 26 & 17.3 & 11 & 7.3 \\
\hline Total & $\mathbf{1 5 0}$ & $\mathbf{1 0 0 . 0}$ & $\mathbf{1 5 0}$ & $\mathbf{1 0 0 . 0}$ \\
\hline
\end{tabular}




\subsubsection{Aid During Flash Flood Events}

Flash flood-affected households receive help from different kinds of governmental and nongovernmental organizations. Middle-earning households are considered more often because they are unwilling to accept aid/relief, unlike people experiencing poverty who do not hesitate to obtain relief from the government and NGOs. In addition, during the questionnaire survey, the local people claimed that the flood relief programs were not distributed accurately, and even wealthy people were nominated for relief by local leaders who were associated with the regent government party (Kamal et al. 2018). The field data (Fig. 12.11a) show that among the surveyed slum households, most of the households (approximately 72.7\%) did not receive any aid during flash floods because they were not able to go to the place where the relief was distributed. The rest of surveyed households (only $27.3 \%$ ) received help. A greater number of households (almost 62\%) in the non-slum area did not receive help (Fig. 12.11b). Because the relief distribution was not sufficient, it was impossible to provide aid to every affected family. Therefore, the majority of households did not receive help during floods; the remaining $38 \%$ of the total households in the non-slum area received help during floods. Nevertheless, the aid amounts distributed were very small. As a result, almost all households (who received help) were dissatisfied with the help.

\subsubsection{Warning Before Flash Flood}

To reduce household vulnerability to flash floods, early warning systems are essential. Flash floods can destroy many lives and assets within a few hours, but if the respective authority can provide timely forecasts of flash floods, the loss of lives can be reduced and asset damage can be condensed. Table 12.12 reveals that of the respondents living in slums, the majority (nearly 62.7\%) were not given forecasts before flash flood events. These respondents had low awareness and insufficient electronic devices (television, radio) that can provide information about flash floods. In comparison, $24 \%$ of respondents received forecasts 1-3 days before flood events. Only 10.7 and $2.7 \%$ of respondents received forecasts $4-6$ days before and more than six days before a flood event, respectively. A total of $16.7 \%$ of those living in non-slum areas did not receive any warning before flash floods occurred, while approximately half of the respondents (about 48\%) received forecasts 4 6 days before floods occurred. The remaining 32.7 and $2.7 \%$ of respondents were warned about flash floods 1-3 days before and more than six days before the floods occurred, respectively (Table 12.12). The results show that slum dwellers are institutionally much more highly vulnerable than non-slum dwellers. 

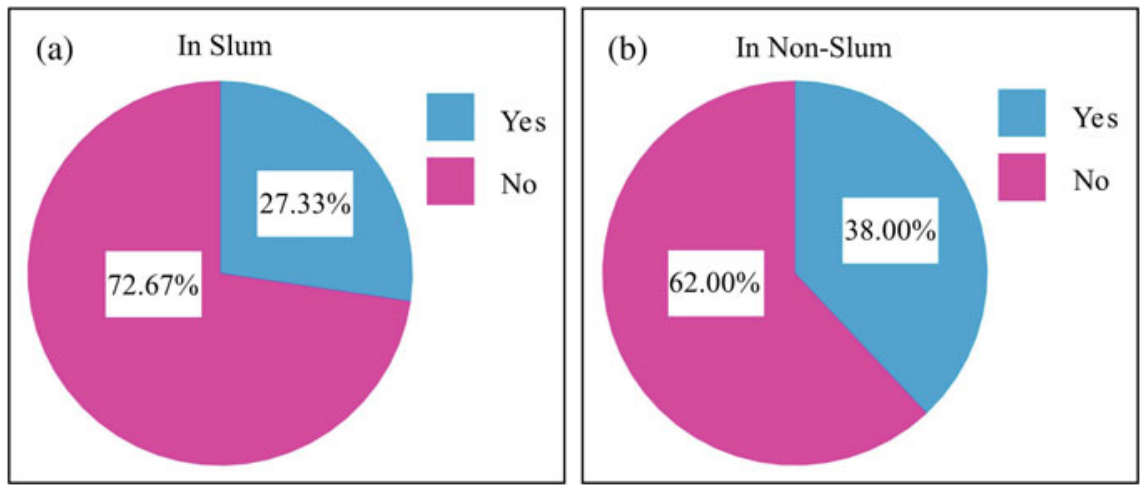

Fig. 12.11 Aid during flood events for a those living in the studied slum area and $\mathbf{b}$ those living in the studied non-slum area

Table 12.12 Warnings received before flash flood events

\begin{tabular}{l|l|l|l|c}
\hline \multirow{2}{*}{ Timing of warning } & \multicolumn{3}{l|}{} & Non-slum \\
\cline { 2 - 5 } & Frequency & Percent & Frequency & Percent \\
\hline None & 94 & 62.7 & 25 & 16.7 \\
\hline 1-3 days before & 36 & 24.0 & 49 & 32.7 \\
\hline 4-6 days before & 16 & 10.7 & 72 & 48.0 \\
\hline More than 6 days before & 4 & 2.7 & 4 & 2.7 \\
\hline Total & $\mathbf{1 5 0}$ & $\mathbf{1 0 0 . 0}$ & $\mathbf{1 5 0}$ & $\mathbf{1 0 0 . 0}$ \\
\hline
\end{tabular}

\subsubsection{Measuring Environmental Vulnerability}

Sanitation problems are major environmental concerns for city dwellers. Very few households in the studied city area enjoy water supply facilities. Poor drainage systems and sanitation can amplify the flash flood vulnerability levels of people living in the city. Floods can contaminate water and damage water pipes, tanks, and pump equipment (Mavhura et al. 2017). This study considered only sanitation and water supply to evaluate Dhaka megacity inhabitants' flash flood vulnerability levels.

\subsubsection{Sanitation}

If a household contains a fragile or poor sanitation system, the household can be easily affected by floods because floodwater can abolish weak systems easily. There are shortages of potable water in the study region during and after long floods. Sanitation and hygiene services are similarly influenced by floods, as broken 
sanitation systems expand pollutants into surface water, which is usually used for showers and other domestic purposes (Richmond et al. 2018). Slum dwellers commonly use communal toilets, twin-pit toilets, and pit latrines. Hanging toilets still exist in some slum clusters. The surveyed data show that approximately $80 \%$ of the slum households used communal ${ }^{4}$ sanitary latrines, whereas $5.3 \%$ had no toilet facilities, and the remaining $15.3 \%$ of households used hanging toilets (Table 12.13). Around 77.3\% of non-slum inhabitants used twin-pit toilets, $13.3 \%$ of households used single-pit ${ }^{5}$ toilets, and the remaining $9.3 \%$ of households used both single-pit and twin-pit lavatories (Table 12.13). This kind of hanging toilet can be easily affected by flash floods and, as a result, might threaten the water supply due to pollution. Additionally, due to damage to their toilets incurred during floods, the surveyed slum dwellers defecated in floodwaters, which is, in fact, harmful to human health. Slum dwellers might be easily affected by contaminated floodwaters in terms of sanitation facilities.

\subsubsection{Water Facility}

Water pollution is another environmental problem for city dwellers. The capability of residents to access hygienic drinking water is an important feature affecting vulnerability to flash floods or any other natural calamities. Moreover, the lack of water resources is another barrier preventing poor people from adapting during floods (Masciopinto et al. 2019). The formal organization (the city corporation) is the most commonly stated water supplier in the community, as residents have low and poor access to this service. Table 12.14 reveals that in the studied slum area, more than half of households (nearly 53.3\%) used supplied water for drinking, and approximately one-fourth of households drank boiled water. The remaining 17.3 and $4.0 \%$ of households used tap and filtered water, respectively, for drinking. Most (almost 69.3\%) household members in the studied non-slum areas drank boiled and filtered water, and the remaining 12.0 and $18.7 \%$ of habitants drank only boiled water and filtered water with a high-quality filter, respectively (Table 12.14). Drinking supplied and tap water causes the residents of slums to be vulnerable to water-borne diseases.

\subsubsection{Spatial Map of Vulnerability}

To evaluate flash flood vulnerability and the intensity and frequency of flood hazards (Hung et al. 2016), vulnerability maps of floods, exposure, and disaster risk reduction (Adnan et al. 2020; Tapsell et al. 2010) have been produced in previous

\footnotetext{
${ }^{4}$ Toilets were used by several households.

${ }^{5}$ The commode is considered as a single pit toilet.
} 
Table 12.13 Sanitation coverage in the study area

\begin{tabular}{l|r|l|c}
\hline Slum & Non-slum & \\
\hline Toilet type & Percent & Toilet type & Percent \\
\hline Communal sanitary latrine & 79.3 & Twin-pit & 77.3 \\
\hline No toilet & 5.3 & Single-pit & 13.3 \\
\hline Hanging & 15.3 & Single + twin-pit & 9.3 \\
\hline Total & $\mathbf{1 0 0 . 0}$ & & $\mathbf{1 0 0 . 0}$ \\
\hline
\end{tabular}

Table 12.14 Types of drinking water in the study area

\begin{tabular}{l|c|l|l}
\hline Slum & Non-slum & \\
\hline Type of drinking water & Percent & Type of drinking water & Percent \\
\hline Filtered & 4.0 & Filtered & 18.7 \\
\hline Boiled & 25.3 & & \\
\hline Tap & 17.3 & Boiled & 12.0 \\
\hline Supply & 53.3 & Boiled + normal filter & 69.3 \\
\hline Total & $\mathbf{1 0 0 . 0}$ & & $\mathbf{1 0 0 . 0}$ \\
\hline
\end{tabular}

studies. Not only flash flood events are responsible for flood disasters; socioeconomic, structural, institutional setup, and environmental conditions also influence flood disasters. In the study region, most households in the slum area were, structurally, very highly vulnerable to future flash floods. Uneven road networks and poor transportation services cause residents living in both slum and non-slum areas to be vulnerable to flash floods. Most slum inhabitants were not aware of or prepared to address any misfortunes. Therefore, people living in slums were more vulnerable to sudden flood hazards than those living in non-slum. The present study demonstrates that most slum inhabitants are socially vulnerable to flash floods, but very few non-slum inhabitants are socially vulnerable to flash floods. Economic factor has a dominating role, influencing people's vulnerability levels to flash flood hazards. Remarkably, the institutional vulnerability levels of people living in slums and non-slums were similar because residents of both areas live under the same institutional framework and consider the issue of institutional vulnerability virtually useless in their regular lives compared to higher-priority economic factors. The environment has great importance for humans, but slum inhabitants live in environmentally risky areas. Slum dwellers might easily be affected by contaminated floodwater in terms of sanitation facilities. In contrast, non-slum inhabitants are environmentally more secure.

The goal of this study is to assess urban households' flash flood vulnerability levels, representing people's vulnerability to flash floods in Dhaka megacity. The map of the spatial vulnerability of residents to flash floods was developed via the aggregation of all vulnerability factors. Figure 12.12 shows that inhabitants of the middle portion of the study area are highly vulnerable to flash floods. The majority 


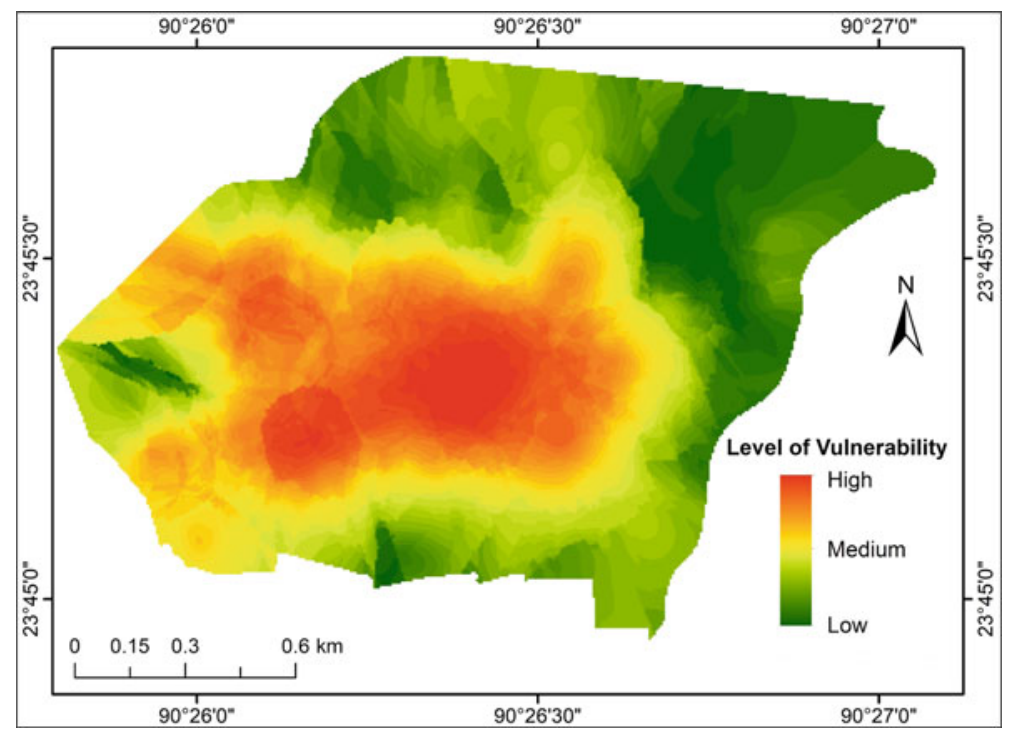

Fig. 12.12 Overall household vulnerability of urban people to floods (based on Huq et al. (2020c))

of people in the study area are moderately vulnerable. Northeastern residents are less vulnerable to future floods than residents in other areas. The vulnerability maps were derived from the household survey data and prepared with a fixed spatial vulnerability scale. Therefore, the maps do not symbolize the individual attributes of inhabitants.

\subsection{Discussion}

Certainly, flash flood is a key problem for the residents of Dhaka city. Most people are anxious about flash floods because during these crises, they have limited access to essential needs, such as food, potable water, and shelter. During and after flood events, finding a dry place to sleep, drying clothes, drinking water, making money, continuing jobs, and accessing food become difficult. Not only flash flood events are responsible for flood disasters; socioeconomic, structural, institutional setup and environmental conditions are also responsible for influencing these disasters. The present study demonstrates that most slum inhabitants are highly socially vulnerable to flash floods due to various social causes, such as poor educational quality, insecure jobs, large family size, and gender influence. On the other hand, the high educational quality, formal professions, and small families of non-slum dwellers cause very few residents of the studied non-slum area to be socially vulnerable to flash flood hazards. The lower educational quality of the slum habitants amplifies 
their vulnerability to flash floods. The non-slum inhabitants are less vulnerable than slum dwellers due to educational quality (Table 12.4). Due to their low educational quality levels, most slum dwellers work as day laborers and thus cannot switch over their occupations in disastrous situations. This is the vital cause of their high vulnerability levels. Considering occupation, in the slum area, most of the household heads work as day laborers or rickshaw pullers. Therefore, when flash floods occur, the day laborers and rickshaw pullers are affected first. Alternatively, those living in the non-slum area are engaged with service and business (Table 12.4). For this reason, the non-slum inhabitants are less vulnerable than slum dwellers are in terms of occupation.

Age plays a large role in intensifying flood vulnerability. Both the slum and non-slum areas are dominated by the working-age group (average 55.95\%), but percentage of the dependent age groups is not negligible (Fig. 12.4). The preparation levels of the slum dwellers are insufficient; approximately $80.7 \%$ of households did not have sufficient preparations to face flash floods. As a result, flash floods can attack them easily. Almost all households of the non-slum area kept dry foods to face disastrous situations (Table 12.6), which makes them less vulnerable to these situations than slum dwellers are. Immediate recovery power can minimize the vulnerability of people to flash flood events. The power of resilience depends on the presence of networks within social systems or neighborhoods. The social networking of slum dwellers is better than that of non-slum dwellers. A great number $(40.7 \%)$ of those living in slum area households go to their relatives living in Dhaka for help, while only $26.7 \%$ of non-slum residents go to their relatives living in Dhaka for help. Interestingly, only $12.7 \%$ of those in slum households go to their relatives living beyond Dhaka, whereas a large $(36.7 \%)$ number of those in non-slums go to their relatives living outside Dhaka to solve their financial problems (Table 12.7). Water-borne sicknesses, flooding in workplaces, or the inability to reach workplaces may take place due to flooded roads; these were the key causes of the inability of people to carry on their jobs during flash flood events. These events significantly influence income loss for most households. Since approximately half of the surveyed households did not save money or reserve food, several families were faced with extreme trouble and could not afford food and medicine during flood events.

Economic factor has a significant role in affecting people's vulnerability levels to flash flood hazards. This study shows that most slum community households are, economically, very highly vulnerable due to their low-income levels. No slum dwellers surveyed in this study area owned any land. A large number $(75.3 \%)$ of households in the slum area kept no savings with which to face future floods or any kind of calamity (Table 12.5). More than $80 \%$ of households did not have any kind of insurance with which to defend against disasters (Fig. 12.7). The results of Vo (2016) recommended that enhancement of insurance registration amount is very important for reducing household vulnerability. The results of this study support the findings of Vo (2016). In the non-slum area, only $8 \%$ of households were, economically, considered to be under very highly vulnerable conditions. Because, only $8 \%$ of the total monthly income levels of the households were between only 12,000 
and 17,000 BDT, and approximately $8 \%$ of the households had no savings (Fig. 12.6 and Table 12.8). In consideration of insurance, non-slum inhabitants had better positions than slum dwellers. Slum dwellers were found to be in highly vulnerable conditions due to their low-income levels. It was found that most people from flash flood-affected regions were engaged with informal jobs. These low-diversified livelihoods cause residents to be more vulnerable to flash floods. The outcomes of the current study are consistent with those of other studies (Kamal et al. 2018). The loan status of the surveyed residents was good because most (about 56\%) households in the slum area had no loans; however, other economic supports, such as land ownership, savings conditions, insurance, and vehicle ownership, were found to be very poor.

Structural components were also responsible for raising or lowering people's flash flood vulnerability levels. In Dhaka megacity, most households in the slum areas are structurally very highly vulnerable to future flash floods. The empirical data show that the housing conditions of slum dwellers are very poor. The largest portion (around $75.3 \%$ ) of the total surveyed slum area residents live in kutcha houses. In the non-slum area, almost all (approximately 100\%) of the inhabitants live in pucca houses (Table 12.10). Additionally, Few and Tran (2010) noted that household structure and household location are also important issues affecting the preparation for and prevention of hazard events. According to most respondents' statements, their locality's road network and transportation system were not good (Fig. 12.10 and Table 12.11). This makes these populations vulnerable to flash floods because they cannot move to a safe place easily during floods. Most of the victims of flood events living in non-slum areas stay at their own affected houses due to worries about their existing property being stolen.

The present study reveals that slum and non-slum residents are mostly vulnerable to flash flood hazards due to inadequate institutional facilities, as the majority of households in slum and non-slum areas (about $72.7 \%$ and $62 \%$, respectively) do not receive any help or relief (e.g., food, drinking water, medical facilities) from the government or NGOs during flash floods (Fig. 12.11). Early warning system is considered as an important tool for reducing the impacts of disasters. Only few slum and non-slum dwellers reported obtaining early warnings before flash floods (Table 12.12). The survey results of Kamal et al. (2018) showed that only $7.5 \%$ of households obtained weather forecasts and attempted to take essential preparation measures for impending flash floods. Approximately $65 \%$ of households did not initiate for protection or preparation measures for potential flash floods. Most people were not aware of effective preparation measures that can be taken to save themselves and avoid losses resulting from flash floods. However, some inhabitants took preparation measures, such as establishing house structures, keeping reserves of dry food, and saving money.

Environmental factor also can intensify the flash flood hazard. The analytical result revealed that most households (about 64.7\%) of the slum are very highly vulnerable to environmental conditions. Because, most of the households of slums use the communal toilet (Table 12.13). A maximum of non-slum inhabitants is moderately vulnerable in terms of environmental conditions. The analytical data 
show the majority (roughly $77.3 \%$ ) households of non-slum use twin-pit type toilets (Table 12.13). In the slum and non-slum area, none of the households uses tube-well water for their daily activities. The household survey results of Pham et al. (2020) demonstrated that nearly $90 \%$ of the community uses natural water for drinking and household purpose. Thus, it makes them vulnerable to health-associated issues due to poor food quality and water safety, and water-borne illnesses are related to water pollution during the flood.

\subsection{Vulnerability Reduction}

The present study recommends an inclusive array of strategies that should be implemented or considered to reduce vulnerability in Dhaka megacity. It is essential to raise people's education levels with free or low-cost educational institutions. Simultaneously, the local government needs to assist people by establishing professional training, for instance, in handcrafts. This might help them increase the income of inhabitants, thus, assisting them in escaping from poverty. The local and central governments can also inspire inhabitants via various measures, such as making and protecting strong dams along rivers, improving potable water quality, building water reservoirs, introducing water treatment plants, providing flash flood early warning systems, and developing infrastructure. Finally, financial assistance must also be provided during flash floods. The following options could be considered to reduce city inhabitants' vulnerability levels and lessen the damage derived from physical, social, institutional, and economic phenomena during flash flood events.

- To undertake a maximum range of communal contributions, invaded communities should be empowered to reduce their vulnerability.

- To reduce economic vulnerability, we need to create different economic activities and income sources for city dwellers.

- Women are often identified as a group that is highly vulnerable to flash flood hazards, so women should be considered a target group in disaster-related programs.

To allow urban areas to become less vulnerable to flash flooding, the following measures should be considered:

\begin{tabular}{|c|c|}
\hline Options & $\begin{array}{l}\text { Possible measures for reducing flash flood vulnerability levels in urban } \\
\text { areas }\end{array}$ \\
\hline $\begin{array}{l}\text { Threshold ability } \\
\text { (damage } \\
\text { inhibition) }\end{array}$ & $\begin{array}{l}\text { - Construction of dams } \\
\text { - Enhancing river volume } \\
\text { - Underground floodways } \\
\text { - Improving urban drainage density } \\
\text { - Reducing stormwater runoff }\end{array}$ \\
\hline Coping ability & - Emergency strategies and timely flash flood warnings \\
\hline
\end{tabular}


(continued)

\begin{tabular}{l|l}
\hline Options & $\begin{array}{l}\text { Possible measures for reducing flash flood vulnerability levels in urban } \\
\text { areas }\end{array}$ \\
\hline $\begin{array}{l}\text { (damage } \\
\text { reduction) }\end{array}$ & $\begin{array}{l}\text { - Better communication with inhabitants } \\
\text { - Elevated major infrastructure and buildings } \\
\text { - Flash flood-proof infrastructure and buildings }\end{array}$ \\
\hline $\begin{array}{l}\text { Recovery ability } \\
\text { (damage }\end{array}$ & - Insurance \\
reduction) & - Emergency funds \\
\hline $\begin{array}{l}\text { Adaptive ability } \\
\text { (damage }\end{array}$ & - Forming flash flood relief organizations \\
reduction) & - Integrating flash flood management and spatial planning \\
\hline
\end{tabular}

\subsection{Conclusions}

Flash flood is a very common and familiar issue in Bangladesh. Dhaka city is not free from the impacts of flash flooding. Residents of slums commonly have low levels of education and are financially poor. Normally, these residents reside in marginalized zones that are in bad conditions and sometimes located in risky areas. Thus, these populations are most vulnerable to flash floods. From the current study's findings, it is obvious that slum inhabitants are more vulnerable to flash flood hazards than non-slum inhabitants are. This study focused on measuring the levels of people's vulnerability to flash flood hazards in urban areas. There is an urgency to conduct more research on this key issue while focusing on residents of slum and non-slum areas in other cities. Paying more attention to the relative importance of various factors, such as social, economic, structural, institutional, political, geographic, and environmental factors, would allow the specific nature of people's vulnerability levels to different hazards to be measured.

There are two kinds of floods in Dhaka megacity: river floods/annual floods and flash floods resulting from heavy rainfall events. In the current study, only flash floods were considered. Risk comprises three components, vulnerability, exposure, and hazard, but this study covers only vulnerability. In future studies, analyses of river floods/annual floods can be conducted while including all the risk components. Secondary data was not available for this study. Parameters/factors are important tools used to assess vulnerability, but identifying these variables is a complex process that requires adherence to certain quality criteria. This study surveyed only 300 households, an estimated $16.85 \%$ of the total population. To mitigate hazards and reduce vulnerability, regular action is needed over a large spatial scale.

This study was exclusively limited to only flash flood-oriented areas. To evaluate vulnerability to flash floods, five factors of vulnerability were applied; other factors could not be applied due to data unavailability. Further studies including other 
factors of vulnerability can be conducted. Further research should be conducted incorporating spatial data for the mapping of vulnerability levels in Dhaka megacity and other cities.

\section{References}

Abdul-Razak M, Kruse S (2017) The adaptive capacity of smallholder farmers to climate change in the northern region of ghana climate. Risk Manage 17:104-122

Adelekan IO (2011) Vulnerability assessment of an urban flood in Nigeria: Abeokuta flood 2007 Natural Hazards 56:215-231

Adger WN (2006) Vulnerability. Global Environ Change 16:268-281

Adnan K, Ying L, Sarker S, Yu M, Eliw M, Sultanuzzaman M, Huq M (2020) Simultaneous adoption of risk management strategies to manage the catastrophic risk of maize farmers in Bangladesh. Geo J

Ahmed I (2016) Building resilience of urban slums in Dhaka, Bangladesh. Procedia Soc Behav Sci 218:202-213

Ahmed MR, Rahaman KR, Kok A, Hassan QK (2017) Remote sensing-based quantification of the impact of flash flooding on the rice production: a case study over northeastern Bangladesh. Sensors 17:2347

Ahsan MN, Warner J (2014) The socioeconomic vulnerability index: a pragmatic approach for assessing climate change led risks - a case study in the south-western coastal Bangladesh. Int J Disaster Risk Reduct 8:32-49

Alam A, Ahmed B, Sammonds P (2020) Flash flood susceptibility assessment using the parameters of drainage basin morphometry in SE Bangladesh. Quat Int

Amoako C, Inkoom DKB (2018) The production of flood vulnerability in Accra, Ghana: re-thinking flooding and informal urbanisation. Urban Studies 55:2903-2922

Andaleeb SS, Siddiqui N, Khandakar S (2007) Patient satisfaction with health services in Bangladesh. Health Policy Plan 22:263-273

Aroca-Jiménez E, Bodoque JM, García JA, Díez-Herrero A (2018) A quantitative methodology for the assessment of the regional economic vulnerability to flash floods. J Hydrol 565:386-399

Aroca-Jiménez E, Bodoque JM, García JA (2020) How to construct and validate an integrated socio-economic vulnerability index: implementation at regional scale in urban areas prone to flash flooding. Sci Total Environ 746:140905

Bahauddin KM, Rahman MM, Ahmed F (2014) Towards urban city with sustainable buildings a model for Dhaka City Bangladesh. Environ Urbanization Asia 5:119-130

Barua U, Akther MS, Islam I (2016) flood risk reduction approaches in Dhaka, Bangladesh. In: Shaw R, Atta ur R, Surjan A, Parvin GA (eds) Urban disasters and resilience in Asia, pp 209226. Butterworth-Heinemann

Berrouet LM, Machado J, Villegas-Palacio C (2018) Vulnerability of socio-ecological systems: a conceptual. Framework Ecol Indic 84:632-647

Bouzelha K, Hammoum H, Saradouni F, Benamar A (2018) Assessment of the vulnerability index of small dams to natural hazards: case study. In: Makhlouf ASH, Aliofkhazraei M (eds) Handbook of materials failure analysis, pp 329-350. Butterworth-Heinemann

Braun B, Aßheuer T (2011) Floods in megacity environments: vulnerability and coping strategies of slum dwellers in Dhaka/Bangladesh. Nat Hazards 58:771-787

Chen G, Huang K, Zou M, Yang Y, Dong H (2019) A methodology for quantitative vulnerability assessment of coupled multi-hazard in chemical industrial park. J Loss Prev Process Ind 58:30-41

Chowdhury EH, Hassan QK (2017) Use of remote sensing data in comprehending an extremely unusual flooding event over southwest Bangladesh. Nat Hazards 88:1805-1823 
Cutter SL, Boruff BJ, Shirley WL (2003) Social vulnerability to environmental hazards. Soc Sci Q $84: 242-261$

de Andrade MMN, Szlafsztein CF (2018) Vulnerability assessment including tangible and intangible components in the index composition: an amazon case study of flooding and flash flooding. Sci Total Environ 630:903-912

de Moor EL, Denollet J, Laceulle OM (2018) Social inhibition, sense of belonging and vulnerability to internalizing problems. J Affect Disord 225:207-213

Dewan AM, Kankam-Yeboah K, Nishigaki M (2005) Assessing flood hazard in greater Dhaka, Bangladesh using SAR imageries with GIS. J Appl Sci(Pakistan) 5:702-707

Dintwa KF, Letamo G, Navaneetham K (2019) Quantifying social vulnerability to natural hazards in Botswana: an application of cutter model. Int J Disaster Risk Reduct 37:101189

Emrich CT, Cutter SL (2011) Social vulnerability to climate-sensitive hazards in the southern United States Weather. Climate Society 3:193-208

Fakhruddin B, Reinen-Hamill R, Robertson R (2019) Extent and evaluation of vulnerability for disaster risk reduction of urban Nuku'alofa, Tonga. Progress Disaster Sci 100017

Few R, Tran PG (2010) Climatic hazards, health risk and response in Vietnam: case studies on social dimensions of vulnerability. Glob Environ Change 20:529-538

Gain AK, Mojtahed V, Biscaro C, Balbi S, Giupponi C (2015) An integrated approach of flood risk assessment in the eastern part of Dhaka City. Nat Hazards 79:1499-1530

Gain AK, Mondal MS, Rahman R (2017) From flood control to water management: a journey of Bangladesh towards integrated water resources management. Water 9:55

Haque CE (2016) We are more scared of the power elites than the floods": adaptive capacity and resilience of wetland community to flash flood disasters in Bangladesh. Int J Disaster Risk Reduct 19:145-158

Hayes S, Desha C, Burke M, Gibbs M, Chester M (2019) Leveraging socio-ecological resilience theory to build climate resilience in transport infrastructure. Transp Rev 39:677-699

Huang D, Zhang R, Huo Z, Mao F, Youhao E, Zheng W (2012) An assessment of multidimensional flood vulnerability at the provincial scale in China based on the DEA method. Nat Hazards 64:1575-1586

Hung L-S, Wang C, Yarnal B (2016) Vulnerability of families and households to natural hazards: a case study of storm surge flooding in Sarasota County. Florida Appl Geogr 76:184-197

Huq ME (2013) Flood hazard, vulnerability and adaptation of slum dwellers in Dhaka. Lambert Academic Publishing, Germany

Huq ME (2017) Analyzing vulnerability to flood hazard of urban people: evidences from Dhaka megacity Bangladesh. Int J Earth Sci Eng 10:585-594

Huq S, Alam M (2003) Flood management and vulnerability of Dhaka City Building Safer Cities: the future of disaster risk Washington, DC, pp 121-135

Huq ME, Hossain MA (2012) Flood hazard and vulnerability of slum dwellers in Dhaka Stamford. J Environ Human Habitat 1:36-47

Huq ME, Hossain MA (2015) Vulnerability framework for flood disaster management. J Geo-Environ 11:51-67

Huq ME et al. (2020a) Measuring vulnerability to environmental hazards: qualitative to quantitative. In: Fahad S, Hasanuzzaman M, Alam M, Ullah H, Saeed M, Ali Khan I, Adnan M (eds) Environment, climate, plant and vegetation growth, pp 421-452. Springer International Publishing, Cham. https://doi.org/10.1007/978-3-030-49732-3_17

Huq ME, Shoeb AZM, Javed A, Shao Z, Hossain MA, Sarven MS (2020b) Measuring vulnerability for city dwellers exposed to flood hazard: a case study of Dhaka City, Bangladesh. In: International conference on urban intelligence and applications, pp 207-215

Huq ME et al (2020) Assessing vulnerability for inhabitants of Dhaka city considering flood-hazard exposure. Geofizika 37(2):97-130. https://doi.org/10.15233/gfz.2020.37.5

Kamal AM, Shamsudduha M, Ahmed B, Hassan SK, Islam MS, Kelman I, Fordham M (2018) Resilience to flash floods in wetland communities of northeastern Bangladesh. Int J Disaster Risk Reduction 31:478-488 
Kamruzzaman M, Saad Awadh A, Madallah A, Nasser A, Muhammad Hameed S, Md. Enamul H (2020) Water resource evaluation and identifying groundwater potential zones in arid area using remote sensing and geographic information system. J Comput Sci 16. https://doi.org/10. 3844/jcssp.2020.266.279

Khatun MA, Rashid MB, Hygen HO (2016) Climate of Bangladesh MET report, 2387-4201

Kothari CR (2004) Research methodology: methods and techniques. New Age International

Masciopinto $\mathrm{C}$ et al (2019) Human health risk assessment for the occurrence of enteric viruses in drinking water from wells: role of flood runoff injections. Sci Total Environ 666:559-571

Masood M, Takeuchi K (2012) Assessment of flood hazard, vulnerability and risk of mid-eastern Dhaka using DEM and 1D hydrodynamic model. Natural Hazards 61:757-770

Masuya A, Dewan A, Corner RJ (2015) Population evacuation: evaluating spatial distribution of flood shelters and vulnerable residential units in Dhaka with geographic information systems. Nat Hazards 78:1859-1882

Mavhura E, Manyena B, Collins AE (2017) An approach for measuring social vulnerability in context: the case of flood hazards in Muzarabani district. Zimbabwe Geoforum 86:103-117

Nayyer S, Huq M, Nana Yaw Danquah T, Akib J, Asif S (2019) Parameters derived from and/or used with digital elevation models (DEMs) for landslide susceptibility mapping and landslide risk assessment: a review ISPRS. Int J Geo-Inf 8

Ogie RI, Pradhan B (2019) Natural hazards and social vulnerability of place: the strength-based approach applied to Wollongong Australia. Int J Disaster Risk Sci 10:404-420

Okayo J, Odera P, Omuterema S (2015) Socio-economic characteristics of the community that determine ability to uptake precautionary measures to mitigate flood disaster in Kano Plains. Kisumu County, Kenya Geoenviron Disasters 2:4-28

Paavola J (2008) Livelihoods, vulnerability and adaptation to climate change in Morogoro Tanzania. Environ Sci Policy 11:642-654

Pandey R et al. (2015) Socio-ecological vulnerability of smallholders due to climate change in mountains: agroforestry as an adaptation measure. Change Adapt Socio-Ecol Syst 1

Pham NTT, Nong D, Garschagen M (2019) Farmers' decisions to adapt to flash floods and landslides in the Northern Mountainous Regions of Vietnam. J Environ Manage 252:109672

Pham NTT, Nong D, Sathyan AR, Garschagen M (2020) Vulnerability assessment of households to flash floods and landslides in the poor upland regions of Vietnam. Climate Risk Manage 28:100215

Rahman R, Salehin M (2013) Flood risks and reduction approaches in Bangladesh. In: Disaster risk reduction approaches in Bangladesh, pp 65-90. Springer

Rahman MA, Islam S (2019) Climate change adaptation in urban areas: a critical assessment of the structural and non-structural flood protection measures in Dhaka. In: Confronting climate change in Bangladesh, pp 161-173. Springer

Richmond A, Myers I, Namuli H (2018) Urban informality and vulnerability: a case study in Kampala, Uganda. Urban Science 2:22

Ruin I, Creutin J-D, Anquetin S, Lutoff C (2008) Human exposure to flash floods-relation between flood parameters and human vulnerability during a storm of September 2002 in Southern France. J Hydrol 361:199-213

Saaty TL (2008) Decision Making with the Analytic Hierarchy Process. Int J Serv Sci 1:83-98

Sarker AA, Rashid AM (2013) Landslide and flashflood in Bangladesh. In: Disaster risk reduction approaches in Bangladesh, pp 165-189. Springer

Sarker M, Bo Y, Yang L, ME H, MM K (2020) Climate change adaptation and resilience through big data. Int J Adv Comput Sci Appl 11:533-539

Sebald C (2010) Towards an integrated flood vulnerability index: a flood vulnerability assessment. Master of Science (MSc)

Shah AA, Ye J, Abid M, Khan J, Amir SM (2018) Flood hazards: household vulnerability and resilience in disaster-prone districts of Khyber Pakhtunkhwa province, Pakistan. Nat Hazards 93:147-165

Shams N (1999) Urban geology of Dhaka city for geohazard mitigation and development planning. University of Dhaka, Dhaka 
Shao Z, Huq ME, Cai B, Altan O, Li Y (2020) Integrated remote sensing and GIS approach using Fuzzy-AHP to delineate and identify groundwater potential zones in semi-arid Shanxi Province, China. Environ Modell Softw 134:104868

Shrestha AB, Shah SH, Karim R (2008) Resource manual on flash flood risk management. Internat. Centre for Integrated Mountain Development, ICIMOD Kathmandu,

Sufia S, GM TI, Zahidul I (2009) Pre-and post-urban wetland area in Dhaka City, Bangladesh: a remote sensing and GIS analysis. J Water Resour Prot 2009

Tapsell S, McCarthy S, Faulkner H, Alexander M (2010) Social vulnerability to natural hazards. CapHaz-Net WP4 Report. Flood Hazard Research Centre-FHRC, Middlesex University, London. http://caphaz-net.org/outcomes-results/CapHaz-Net_WP4_Social-Vulnerability2.pdf. Access on Sept 2012

Taylor J (1840) A sketch of the topography and statistics of Dacca. Military Orphan Press, GH Huttmann

Taylor J (1849) Topography of Dhaka East India Company, Dhaka

Uddin K, Matin MA, Meyer FJ (2019) Operational flood mapping using multi-temporal sentinel-1 SAR images: a case study from Bangladesh. Remote Sensing 11:1581

UNICEF (2009) Bangladesh Bureau of Statistics. 2018 Bangladesh Drinking Water Quality Survey

Vo T (2016) Risk aversion and the impact of health insurance on household vulnerability: new evidence from rural Vietnam

Wmo G, Gwp G (2016) Handbook of drought indicators and indices geneva: world meteorological organization (WMO) and global water partnership (GWP)

Zakour MJ, Swager CM (2018) Vulnerability-plus theory: the integration of community disaster vulnerability and resiliency theories. In: Zakour MJ, Mock NB, Kadetz P (eds) Creating Katrina, Rebuilding Resilience. Butterworth-Heinemann, pp 45-78

Open Access This chapter is licensed under the terms of the Creative Commons Attribution 4.0 International License (http://creativecommons.org/licenses/by/4.0/), which permits use, sharing, adaptation, distribution and reproduction in any medium or format, as long as you give appropriate credit to the original author(s) and the source, provide a link to the Creative Commons license and indicate if changes were made.

The images or other third party material in this chapter are included in the chapter's Creative Commons license, unless indicated otherwise in a credit line to the material. If material is not included in the chapter's Creative Commons license and your intended use is not permitted by statutory regulation or exceeds the permitted use, you will need to obtain permission directly from the copyright holder. 